Article

\title{
Quantitative Assessment of Tetrel Bonding Utilizing Vibrational Spectroscopy
}

\author{
Daniel Sethio $^{+}\left(\mathbb{D}\right.$, Vytor Oliveira $^{+}(\mathbb{D})$ and Elfi Kraka * \\ Computational and Theoretical Chemistry Group, Department of Chemistry, Southern Methodist University, \\ 3215 Daniel Avenue, Dallas, TX 75275-0314, USA; sethio.daniel@gmail.com (D.S.); vytor3@gmail.com (V.O.) \\ * Correspondence: ekraka@gmail.com; Tel.: +1-214-768-1609 \\ + These authors contributed equally to this work.
}

Academic Editor: Steve Scheiner

Received: 2 October 2018; Accepted: 20 October 2018; Published: 25 October 2018

check for

\begin{abstract}
A set of 35 representative neutral and charged tetrel complexes was investigated with the objective of finding the factors that influence the strength of tetrel bonding involving single bonded $\mathrm{C}, \mathrm{Si}$, and $\mathrm{Ge}$ donors and double bonded $\mathrm{C}$ or Si donors. For the first time, we introduced an intrinsic bond strength measure for tetrel bonding, derived from calculated vibrational spectroscopy data obtained at the CCSD(T)/aug-cc-pVTZ level of theory and used this measure to rationalize and order the tetrel bonds. Our study revealed that the strength of tetrel bonds is affected by several factors, such as the magnitude of the $\sigma$-hole in the tetrel atom, the negative electrostatic potential at the lone pair of the tetrel-acceptor, the positive charge at the peripheral hydrogen of the tetrel-donor, the exchange-repulsion between the lone pair orbitals of the peripheral atoms of the tetrel-donor and the heteroatom of the tetrel-acceptor, and the stabilization brought about by electron delocalization. Thus, focusing on just one or two of these factors, in particular, the $\sigma$-hole description can only lead to an incomplete picture. Tetrel bonding covers a range of -1.4 to $-26 \mathrm{kcal} / \mathrm{mol}$, which can be strengthened by substituting the peripheral ligands with electron-withdrawing substituents and by positively charged tetrel-donors or negatively charged tetrel-acceptors.
\end{abstract}

Keywords: noncovalent interactions; weak interactions; tetrel bonding; intrinsic bond strength; local stretching force constant; $\operatorname{CCSD}(\mathrm{T})$

\section{Introduction}

Noncovalent interactions (NCIs) have received increasing attention in the last two decades [1-3] due to their technological and fundamental importance in physics, chemistry, and biology [4-6]. Despite of the fact that NCIs are weak compared to covalent bonds (about an order of magnitude smaller), the importance of NCIs absolutely cannot be neglected [7-9]. They are ubiquitous and play a significant role in determining the properties of matter from small molecules to supramolecular systems like DNA and proteins [7,10]. They stabilize molecular structures [11,12], construct supramolecular materials [13], lower the activation energy of chemical reactions [14], and regulate the properties of crystal materials [15]. A series of different types of NCIs has been reported, namely, hydrogen bonds [16-22], aerogen bonds (group 18) [23-26], halogen bonds (Group 17) [27-32], chalcogen bonds (Group 16) [33-37], pnicogen bonds (Group 15) [38-42], tetrel bonds (Group 14) [43-49], and triel bonds (Group 13) [50,51].

Recently, tetrel bonding has found many applications due to its unique properties, such as strength, directionality, and origin of attraction [52]. Tetrel bonds play an important role in crystal engineering and supramolecular chemistry as a new potential molecular linker $[44,53]$ and in dynamical processes such as protein folding and ligand-acceptor interactions [54-56]. Tetrel bonds also play an important role in the preliminary stages of SN2 reactions [57] and hydrophobic interactions [58,59]. 
The formation of tetrel bonds can be understood as an interaction between an electron-deficient tetrel atom of a Lewis acid (tetrel donor, T-donor) and an electron-rich of a Lewis base (tetrel acceptor, T-acceptor) (see Figure 1) [53]. The Lewis base (T-acceptor) can be any electron-rich entity possesing a lone pair [60-63], a $\pi$-system [55,64], an anion [44,65], etc. To explain the formation of a tetrel bond via $\sigma$-hole interactions, Politzer, Murray, and Clark suggested an interaction between a region of positive electrostatic potential as a result of diminished electron density on the tetrel atom (T-donor) and a region of negative electrostatic potential on an electron-rich atom (T-acceptor) [3,58,66-68]. The diminished electron density on the tetrel atom occurs as a result of electrons being mostly localized in the bonding region, which leaves a deficiency of electronic density in the outer lobe of the $p$-type valence orbital along the extension of the covalent bonding on the tetrel atom [69].

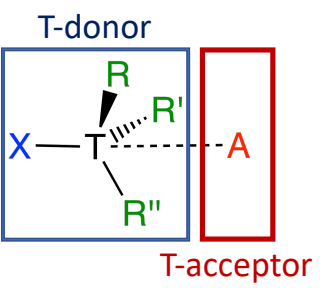

Figure 1. Schematic representation of tetrel complexes between the electron-deficient tetrel atom of a Lewis acid (tetrel donor, T-donor, $\mathrm{T}=\mathrm{C}, \mathrm{Si}, \mathrm{Ge}$ ) and the electron-rich tetrel atom of a Lewis base (tetrel acceptor, T-acceptor, $\mathrm{A}=\mathrm{FH}, \mathrm{OH}_{2}, \mathrm{NH}_{3}, \mathrm{Cl}^{-}$).

A series of experimental studies was conducted to identify and characterize tetrel bonding. The first convincing evidence of tetrel bonding was reported by Jönson and co-workers in 1975, where they observed that the carbon atoms of the carbon dioxide dimer can attractively interact with the lone pair of the oxygen of water [70] which was confirmed nine years later via microwave spectroscopic analysis by Klemperer and co-workers [71]. Recently, Guru-Row and co-workers provided experimental evidence of tetrel bonding based on an X-ray charge density analysis [43]. They revealed the existence of a bond path connecting the oxygen atom with the $-\mathrm{CH}_{3}$ carbon atom in $\mathrm{R}_{3} \mathrm{~N}^{+}-\mathrm{CH}_{3} \cdots \mathrm{OH}$ complexes [43]. Mitzel and co-workers discussed $\mathrm{Si} \cdots \mathrm{N}$ tetrel bonding in the crystalline $\mathrm{Si}\left(\mathrm{ONMe}_{2}\right)_{4}[72,73]$. Evidence of tetrel bonding has also been observed by NMR spectroscopy [74]. The chemical shifts, quadrupolar couplings, and J-coupling are sensitive to the presence of tetrel bonding. For example, the J-coupling constant for (secondary) tetrel bonds has a magnitude of about $3 \mathrm{~Hz}$ [75].

The strength of tetrel bonding can be enhanced by cooperative effects [76-78] in conjunction with hydrogen bonding [79,80], halogen bonding [80], chalcogen bonding [81,82], lithium bonding [83], or with other tetrel bonding [84]. Cooperative effects in tetrel bonding [85-87] play an important role in crystal materials, chemical reactions, and biological systems $[78,88,89]$. Thus, the understanding of the strength and the nature of tetrel bonding is the key to understanding its properties. The molecular electrostatic potential $\left(\mathrm{V}_{s}\right)$ and its maximum value $\left(\mathrm{V}_{s, \max }\right)$ are commonly used measures to quantify the strength of the $\sigma$-hole interaction $[58,90,91]$. A limited correlation between the interaction energies and the value of the $\mathrm{V}_{s, \max }$ has been reported by several authors $[27,28,61,66,92]$. However, very recently, Scheiner and co-workers pointed out that the maximum magnitude of the molecular electrostatic potential is not an ideal bond strength indicator $[93,94]$. Therefore, there is an urgent need for a qualified intrinsic bond strength descriptor, which we address in the present work.

One of the most common measures for quantifying the chemical bond strength is the bond dissociation energy (BDE) or the bond dissociation enthalpy (BDH). It has been shown that the BDE or $\mathrm{BDH}$ has the limitation of describing the intrinsic strength of a bond [95-98] because it includes the geometry relaxation of the fragments as well as the reorganization of the electron density. The intrinsic bond strength based on the local mode force constants $k^{a}$ measures the bond strength with only infinitesimal changes in the electronic structure of the molecule, thus excluding misleading additional 
contributions from the relaxation of the fragments. Many examples show that a chemical bond may have a large value of $k^{a}$ but a low BDE, vice versa [40,96,97].

Vibrational spectroscopy is an important tool that has been used to identify and characterize small-to-medium-sized molecules [99-101]. However, normal vibrational modes are of limited use as bond strength measure due to mode-mode coupling. A major breakthrough was achieved by the work of Konkoli and Cremer where the use of vibrational spectroscopy as an intrinsic bond strength measure via local vibrational modes was refined [102,103]. The intrinsic strength of chemical bonds is probed using the associated local stretching force constants $k^{a}$ [104-106]. The local stretching force constants $k^{a}$ have been successfully used to determine the intrinsic bond strength of covalent bonds such as CC bonds [105,107-109], NN bonds [110], NF bonds [98], CO bonds [111], and $\mathrm{CX}(\mathrm{X}=\mathrm{F}, \mathrm{Cl}, \mathrm{Br}, \mathrm{I})$ bonds [112-115] as well as weak chemical interactions such as hydrogen bonding [18-22], halogen bonding [30,116-118], pnicogen bonding [40-42], chalcogen bonding [96,97], and recently, $\mathrm{BH} \cdots \pi$ interactions $[119,120]$. In this study, we investigate the strength and the nature of the tetrel bonds for a representative set of 35 complexes (see Figure 2) and also compare tetrel bonding with halogen and chalcogen bonding.

$$
\begin{aligned}
& \text { 1, } \\
& \text {-638 } \\
& \begin{array}{lll}
7, \mathrm{C}_{3 \mathrm{v}} & \mathbf{8}, \mathrm{C}_{\mathrm{s}} & \mathbf{9}, \mathrm{C}_{\mathrm{s}}
\end{array} \\
& \text { (205) } \\
& 13, \mathrm{C}_{\mathrm{s}} \quad 14, \mathrm{C}_{3 \mathrm{v}} \quad 15, \mathrm{C}_{\mathrm{s}} \\
& \text {-655 } \\
& \text { (173) } \\
& 346{ }^{\mathrm{H}} \quad 347 \\
& -1034 \stackrel{\mathrm{N}}{\mathrm{N}}-\mathrm{H} \\
& \begin{array}{c}
\mathrm{O}=\mathrm{C}=\mathrm{O} \\
-486 \quad 968 \quad-48
\end{array} \\
& \begin{array}{ll}
344 \\
\mathrm{~S}=\mathrm{C}=\mathrm{C} \\
47
\end{array} \\
& \text { O= }
\end{aligned}
$$
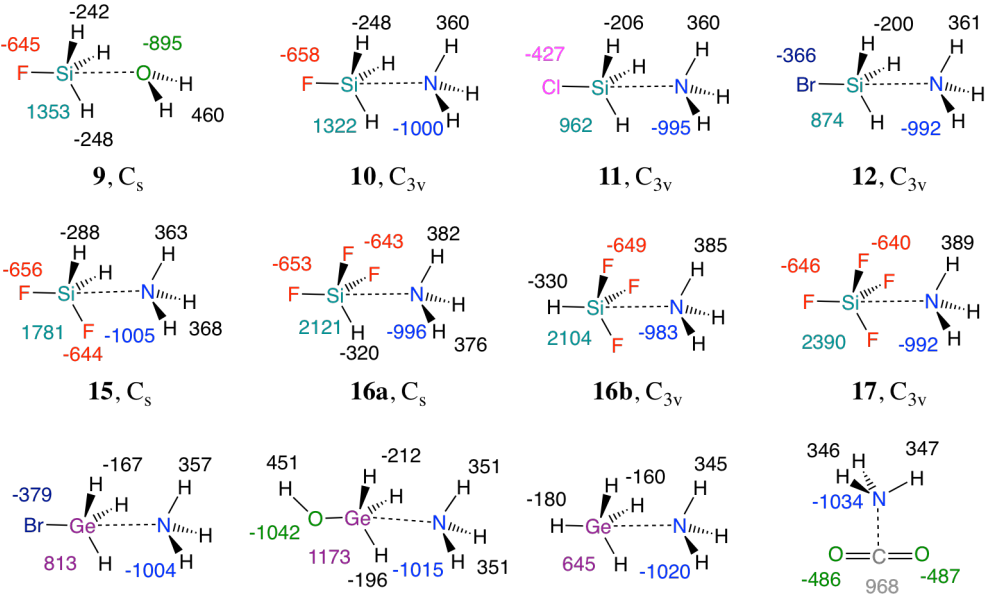

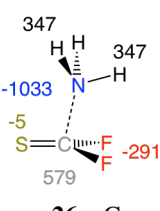
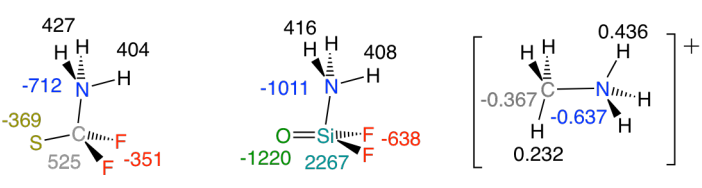

$$
\begin{aligned}
& 27, \mathrm{C}_{\mathrm{s}}
\end{aligned}
$$

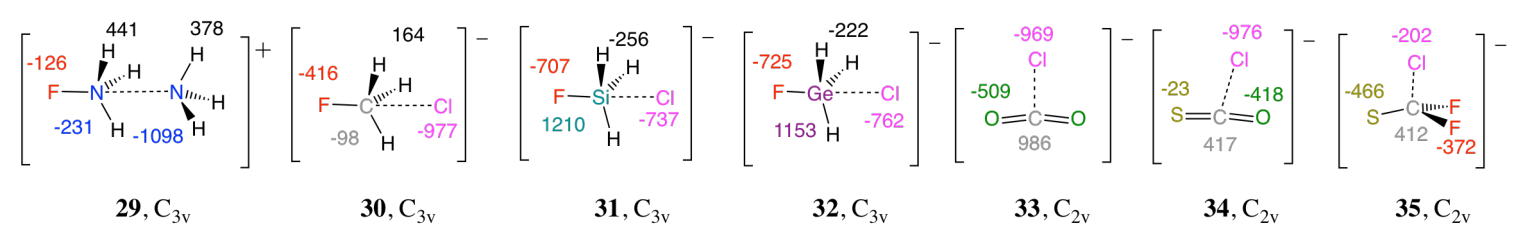

Figure 2. Schematic representation of complexes 1-35 with atomic charges (in me) from the natural population analysis calculated at the $\operatorname{CCSD}(\mathrm{T})$ /aug-cc-pVTZ level of theory. Colors are used to correlate charges to specific atoms.

The main objectives of the present work are (i) to quantify the impact of changing the tetrel atom, its substituents, and the tetrel acceptor on the tetrel bond strength; (ii) to better understand 
the interplay between various electronic effects such as electrostatics, covalent contributions to tetrel bonding, exchange-repulsion between the tetrel acceptor and the peripheral ligands ( $R, R^{\prime}$, and $\left.R^{\prime \prime}\right)$ of the tetrel-donor, etc.; (iii) to compare the strength of tetrel bonds with halogen (XBs), chalcogen $(\mathrm{ChB})$, and pnicogen bonds (PnB); and (iv) to develop an effective strategy to tune the strength of the tetrel bond.

\section{Computational Methods}

To evaluate the key factors that influence the strength of the tetrel bonds, geometry optimizations and normal vibrational modes of complexes 1-35 (see Figure 2), monomers 36-60 (see Table 2, Figure 3, and Supporting Information Figure S1), and reference molecules R1-R2 were calculated using the coupled cluster theory with singles, doubles, and perturbative triples (CCSD(T)) $[121,122]$ in combination with the Dunning's aug-cc-pVTZ basis set [123-125] which contains diffuse basis functions for describing the charge distribution of hetero-atoms, anions, and also, the dispersion interactions in tetrel bonds. All CCSD $(\mathrm{T})$ calculations were carried out using a convergence criterion of $10^{-7}$ Hartree bohr ${ }^{-1}$ for geometry and a threshold of $10^{-9}$ for self-consistent field and CC-amplitudes.

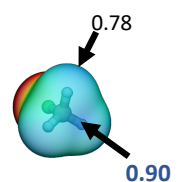

36

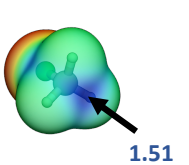

42

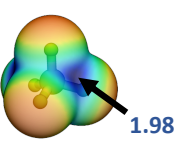

48

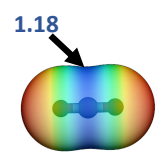

54

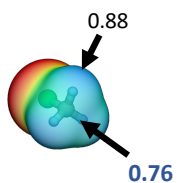

37

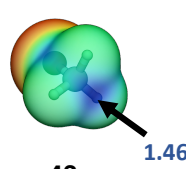

43

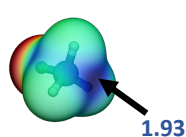

49

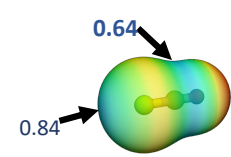

55

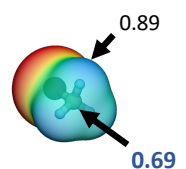

38

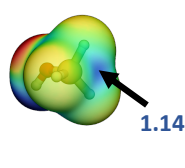

44

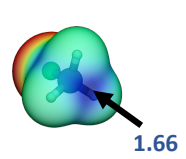

50

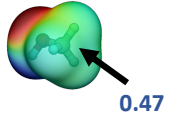

39

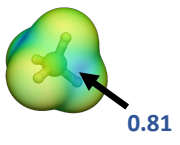

45

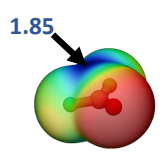

56

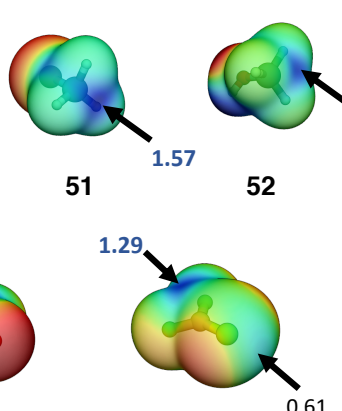

57

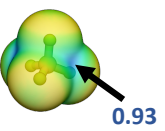

40

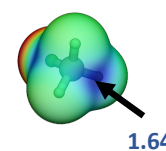

41

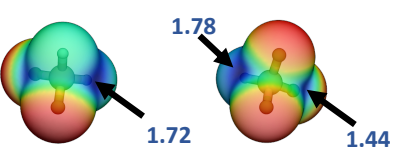

47

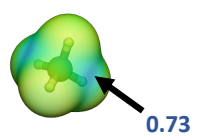

53

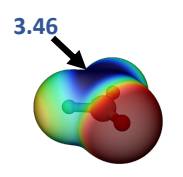

58

Figure 3. Molecular electrostatic potential of neutral tetrel-donors mapped onto the 0.001 a.u electron density surface. Blue and red correspond, respectively, to the positive and negative potential. The extreme values are $\pm 1.9 \mathrm{eV}$. The $\mathrm{V}_{s_{\max }}$ at the tetrel $\sigma$ or $\pi$-hole are given in bold blue, while the $\mathrm{V}_{S_{\max }}$ at the $\mathrm{H}(36,37,38)$ and at the chalcogen atoms $(55,57)$ are shown in black. Calculated at the $\operatorname{CCSD}(\mathrm{T}) /$ aug-cc-pVTZ level of theory.

Normal vibrational modes were converted into local vibrational modes using the Konkoli-Cremer method [102-104,107]. The electronic and mass coupling between normal vibrational modes were eliminated using the mass-decoupled analogue of the Wilson equation $[107,126]$. The resulting local vibrational modes, which were free from any mode-mode coupling, were associated with a given internal coordinate $q_{n}$ (bond length, bond angle, dihedral angle, etc.), which could be connected to normal vibrational modes in an one-to-one relationship via the Adiabatic Connection Scheme (ACS) [104,108]. The local force constant $k^{a}$, obtained from the corresponding local vibrational mode, was used to measure the intrinsic bond strength of the tetrel bonds. 
For simplification, the local force constant $k^{a}$ was converted to the bond strength order (BSO $n$ ) using a power relationship of the generalized Badger rule [127]:

$$
n=a\left(k^{a}\right)^{b} .
$$

The constants $a=0.418$ and $b=0.564$ were obtained by two references of well-defined bond order, namely the $\mathrm{FF}$ bond in $\mathrm{F}_{2}(n=1.0)$ and the three-center-four-electron bond in $\mathrm{F}_{3}{ }^{-}(n=0.5)$, as previously done in a study of halogen bonds [30] and other noncovalent interactions [117].

The binding energy was separated into two contributions:

$$
\Delta E=E_{i n t}+E_{d e f} .
$$

$\mathrm{E}_{\text {int }}$ is the interaction energy for the frozen geometry of the monomers, and the deformation energy $\left(\mathrm{E}_{d e f}\right)$ is the energetic difference between the monomers' frozen geometry and their minimum energy geometry. The counterpoise correction (CP) [128] is usually used to eliminate the basis set superposition error (BSSE) present in $\mathrm{E}_{\text {int }}$. However, BSSE often compensates for the error caused by an incomplete basis set; consequently, uncorrected $\mathrm{E}_{\text {int }}$ values can be closer to the complete basis set limit (CBS) $[117,129]$. To test if this was the case, we compared CP-corrected and uncorrected $\operatorname{CCSD}(\mathrm{T})$ /aug-cc-pVTZ results to the ones obtained using the more saturated pentuple zeta basis set aug-cc-pV5Z [123] (see Supporting Information Table S1). The latter results were obtained by employing the domain-based local pair natural orbital (DLPNO) $[130,131]$ approximation to CCSD(T) using a tight convergence criteria to ensure that the errors caused by the DLPNO approximation were negligible. It turned out that the uncorrected $\operatorname{CCSD}(\mathrm{T}) /$ aug-cc-pVTZ values of $\mathrm{E}_{\text {int }}$ were, on average, closer to the CP-corrected and uncorrected DLPNO-CCSD(T)/aug-cc-pV5Z results than the CP-corrected CCSD(T)/aug-cc-pVTZ values (see Supporting Information Tables S1 and S2). Therefore, in the next sections, only $\Delta \mathrm{E}$ values without counterpoise correction are discussed (see Table 1).

Table 1. Summary of energetics, electron density, energy density, geometric, bond strength order, and vibrational spectroscopy data for complexes $1-35$ *.

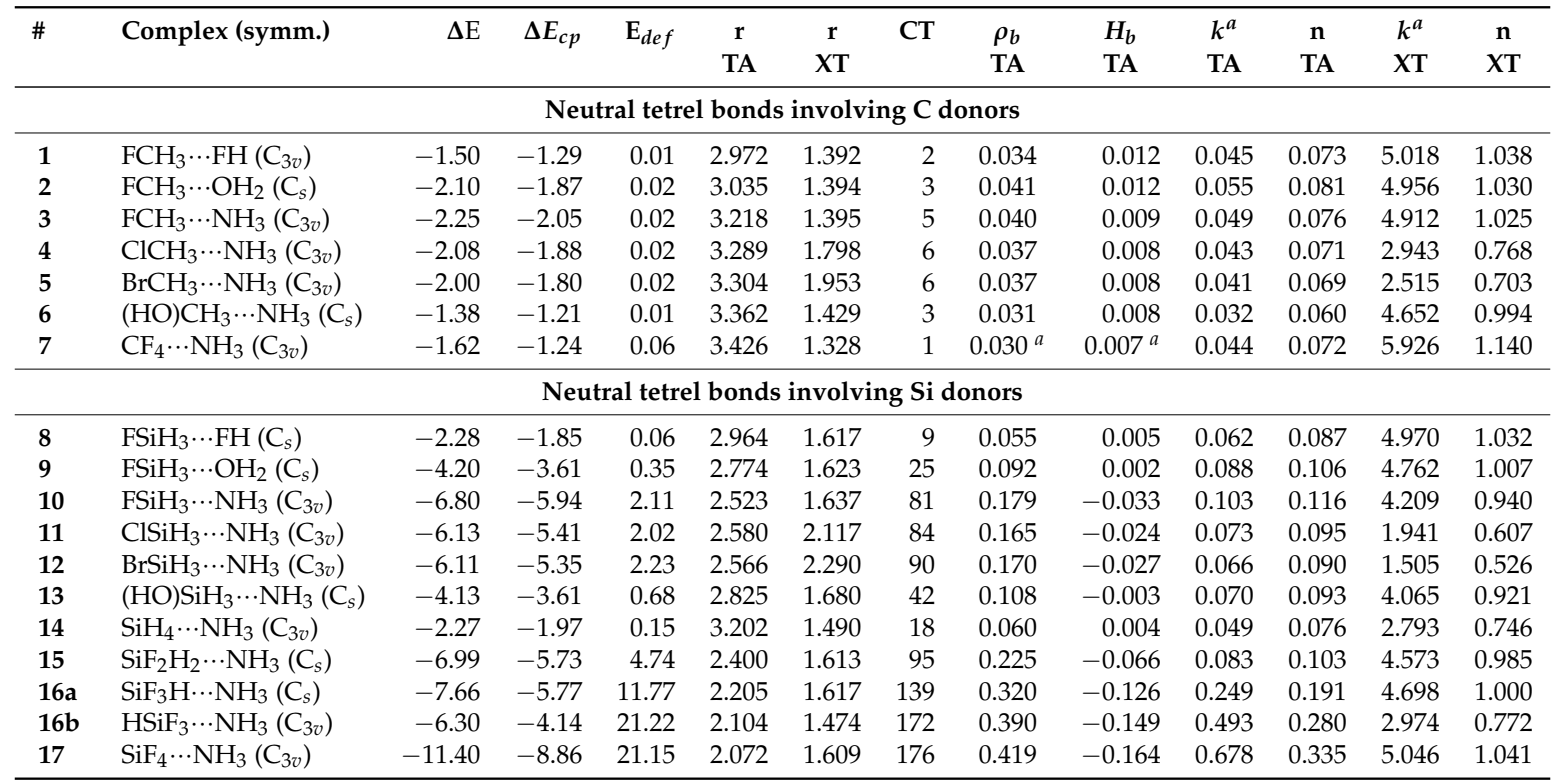


Table 1. Cont.

\begin{tabular}{|c|c|c|c|c|c|c|c|c|c|c|c|c|c|}
\hline$\#$ & Complex (symm.) & $\Delta \mathrm{E}$ & $\Delta E_{c p}$ & $\mathrm{E}_{d e f}$ & $\begin{array}{c}\mathbf{r} \\
\mathrm{TA}\end{array}$ & $\begin{array}{c}\mathbf{r} \\
\mathrm{XT}\end{array}$ & $\mathrm{CT}$ & $\begin{array}{l}\rho_{b} \\
\text { TA }\end{array}$ & $\begin{array}{l}H_{b} \\
\text { TA }\end{array}$ & $\begin{array}{l}k^{a} \\
\text { TA }\end{array}$ & $\begin{array}{c}\mathbf{n} \\
\text { TA }\end{array}$ & $\begin{array}{l}k^{a} \\
\mathrm{XT}\end{array}$ & $\begin{array}{c}\mathbf{n} \\
\mathrm{XT}\end{array}$ \\
\hline \multicolumn{14}{|c|}{ Neutral tetrel bonds involving Ge donors } \\
\hline 19 & $\mathrm{ClGeH}_{3} \cdots \mathrm{NH}_{3}\left(\mathrm{C}_{3 v}\right)$ & -6.22 & -5.75 & 1.07 & 2.755 & 2.216 & 64 & 0.134 & -0.001 & 0.103 & 0.116 & 1.921 & 0.604 \\
\hline 20 & $\mathrm{BrGeH}_{3} \cdots \mathrm{NH}_{3}\left(\mathrm{C}_{3 v}\right)$ & -6.01 & -5.53 & 1.07 & 2.776 & 2.375 & 66 & 0.132 & 0.000 & 0.097 & 0.112 & 1.591 & 0.543 \\
\hline 21 & $(\mathrm{HO}) \mathrm{GeH}_{3} \cdots \mathrm{NH}_{3}\left(\mathrm{C}_{s}\right)$ & -4.58 & -4.18 & 0.50 & 2.910 & 1.818 & 39 & 0.101 & 0.004 & 0.089 & 0.107 & 3.49 & 0.845 \\
\hline 23 & $\mathrm{CO}_{2} \cdots \mathrm{NH}_{3}\left(\mathrm{C}_{\mathrm{s}}\right)$ & -3.09 & -2.84 & 0.11 & 2.922 & 1.167 & 5 & 0.107 & 0.002 & 0.079 & 0.100 & 15.183 & 1.938 \\
\hline 24 & $\mathrm{SCO} \cdots \mathrm{NH}_{3}\left(\mathrm{C}_{s}\right)$ & -1.97 & -1.69 & 0.02 & 3.209 & 1.573 & 3 & 0.046 & 0.009 & 0.047 & 0.074 & 7.081 & 1.260 \\
\hline 25 & $\mathrm{CF}_{2} \mathrm{O} \cdots \mathrm{NH}_{3}\left(\mathrm{C}_{s}\right)$ & -5.55 & -4.82 & 0.27 & 2.687 & 1.178 & 12 & 0.113 & 0.005 & 0.122 & 0.127 & 14.393 & 1.880 \\
\hline $26 a$ & $\mathrm{CF}_{2} \mathrm{~S} \cdots \mathrm{NH}_{3}\left(\mathrm{C}_{\mathrm{s}}\right)$ & -3.91 & -3.23 & 0.11 & 2.897 & 1.607 & 9 & 0.078 & 0.008 & 0.086 & 0.105 & 6.397 & 1.190 \\
\hline $26 b$ & $\mathrm{CF}_{2} \mathrm{~S} \cdots \mathrm{NH}_{3}\left(\mathrm{C}_{\mathrm{s}}\right)$ & 1.45 & 4.28 & 24.13 & 1.587 & 1.701 & 545 & 1.388 & -1.339 & 1.414 & 0.508 & 3.828 & 0.891 \\
\hline 29 & $\mathrm{FNH}_{3}{ }^{+} \ldots \mathrm{NH}_{3}\left(\mathrm{C}_{3 v}\right)$ & -23.14 & -22.77 & 0.43 & 2.619 & 1.374 & 35 & 0.142 & 0.012 & 0.364 & 0.236 & 5.226 & 1.062 \\
\hline 30 & $\mathrm{FCH}_{3} \cdots \mathrm{Cl}^{-}\left(\mathrm{C}_{3 v}\right)$ & -9.77 & -9.34 & 0.39 & 3.179 & 1.419 & 23 & 0.064 & 0.010 & 0.128 & 0.131 & 4.155 & 0.933 \\
\hline 31 & $\mathrm{FSiH}_{3} \cdots \mathrm{Cl}^{-}\left(\mathrm{C}_{3 v}\right)$ & -20.73 & -19.49 & 12.03 & 2.504 & 1.703 & 263 & 0.277 & -0.115 & 0.370 & 0.238 & 2.793 & 0.746 \\
\hline 32 & $\mathrm{FGeH}_{3} \cdots \mathrm{Cl}^{-}\left(\mathrm{C}_{3 v}\right)$ & -26.10 & -25.09 & 10.71 & 2.566 & 1.892 & 238 & 0.290 & -0.069 & 0.455 & 0.268 & 2.451 & 0.693 \\
\hline 33 & $\mathrm{CO}_{2} \cdots \mathrm{Cl}^{-}\left(\mathrm{C}_{s}\right)$ & -7.45 & -6.99 & 1.44 & 2.920 & 1.170 & 31 & 0.107 & 0.002 & 0.109 & 0.120 & 14.879 & 1.916 \\
\hline 34 & $\mathrm{SCO} \cdots \mathrm{Cl}^{-}\left(\mathrm{C}_{s}\right)$ & -5.36 & -4.96 & 0.52 & 3.143 & 1.581 & 24 & 0.073 & 0.006 & 0.079 & 0.100 & 6.568 & 1.208 \\
\hline 35 & $\mathrm{CF}_{2} \mathrm{~S} \cdots \mathrm{Cl}^{-}\left(\mathrm{C}_{s}\right)$ & -16.81 & -13.83 & 32.63 & 1.898 & 1.725 & 798 & 1.031 & -0.593 & 1.100 & 0.441 & 3.414 & 0.835 \\
\hline & $\begin{array}{l}* \text { Binding energies }(\triangle \\
\text { upon complexation }( \\
\text { the TA critical point } \\
\text { analysis (NPA) char } \\
\text { mdyn/ } \AA \text { and bond } \\
\text { a Calculated at a cag }\end{array}$ & $\begin{array}{l}\text {, counter } \\
\text { ef) in kca } \\
\text { in } \mathrm{e} / \AA^{3} \text {, } \\
\text { transfer } \\
\text { ength or }\end{array}$ & mili- & $\begin{array}{l}\text { ed b } \\
\text { nd c } \\
\text { ty at } \\
\text { tron }\end{array}$ & $\begin{array}{l}\text { ance } \\
\text { e TA } \\
\text { me). }\end{array}$ & $\begin{array}{l}\text { itica } \\
\text { A ar }\end{array}$ & 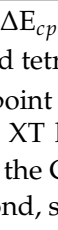 & $\begin{array}{l}b \text { in } \\
\mathrm{cal}\end{array}$ & tree/ & $\mathrm{Na}$ & po & $\begin{array}{l}\text { ergies } \\
\text { sity at } \\
\text { lation } \\
\left.\mathrm{k}^{a}\right) \text { in }\end{array}$ & \\
\hline
\end{tabular}

$\operatorname{CCSD}(\mathrm{T})$ calculations were performed using the CFOUR program [132,133], whereas DLPNO$\operatorname{CCSD}(\mathrm{T})$ calculations were done in ORCA 4.0 [134]. Analytical vibrational frequencies were used to verify that each equilibrium geometry obtained by $\operatorname{CCSD}(\mathrm{T})$ corresponded to a geometry minimum. The charge distribution was calculated with the natural population analysis (NPA) within the Natural Bond Orbital (NBO) scheme $[135,136]$ using the NBO6 program $[137,138]$. The electron density $\rho(r)$ and the energy density $\mathrm{H}(\mathrm{r})$ at the $\mathrm{T} \cdots \mathrm{A}$ (T: tetrel atom and A: tetrel-acceptor) electron density critical point (r) were calculated using the AIMALL program [139]. The molecular electrostatic potentials of T-donors and T-acceptors mapped onto the $0.001 \mathrm{e} / \mathrm{bohr}^{3}$ electron density surface were calculated using the Multiwfn3.5 [140] program. Noncovalent interaction (NCI) plots were calculated using the NCIplot program [141]. NBO charges, as well as, $\mathrm{H}(\mathrm{r}), \rho(r)$ and $\mathrm{V}(\mathrm{r})$ were derived from CCSD(T) response densities obtained from CFOUR calculations with the help of MOLBO and Molden2AIM scripts [142]. Local mode force constants and frequencies were calculated using the COLOGNE18 program package [143].

\section{Results and Discussion}

Table 1 summarizes the complex binding energy $\Delta \mathrm{E}$, the counterpoise corrected binding energy $\Delta \mathrm{E}_{c p}$, the monomers' deformation energy $\mathrm{E}_{\text {def }}$, the distance $\mathrm{r}(\mathrm{TA})$ between the tetrel-donor atom $(\mathrm{T}=\mathrm{C}, \mathrm{Si}$ or $\mathrm{Ge})$ and an heteroatom $\left(\mathrm{A}=\mathrm{F}, \mathrm{O}, \mathrm{N}\right.$ or $\left.\mathrm{Cl}^{-}\right)$of the tetrel-acceptor (T-acceptor), also called the tetrel bond (TB) distance, the distance $r(\mathrm{XT})$ between the $\mathrm{T}$ donor atom and the donor group or atom $(\mathrm{X}=\mathrm{H}, \mathrm{F}, \mathrm{Cl}, \mathrm{Br}, \mathrm{OH},=\mathrm{O}$ or $=\mathrm{S})$, the intermonomer charge transfer $(\mathrm{CT})$ obtained from the natural population analysis (NPA), the electron density $\rho_{b}$ and the energy density $\mathrm{H}_{b}$ at the density critical point associated with TB, the local stretching force constant of TA $\left(\mathrm{k}^{a}(\mathrm{TA})\right)$ and XT $\left(\mathrm{k}^{a}(\mathrm{XT})\right)$ and the BSO $n$ of the TA and XT. The calculated NBO atomic charges are given in Figure 2. $\mathrm{T}$ donor properties such as the maximum electrostatic potential at the $\sigma$-hole region of the tetrel atom $\left(\mathrm{V}_{s_{\max }}\right)$, the total dipole moment, and the isotropic polarizability are listed in Table 2. The BSO $n$ 
values of all TB are given as functions of their local stretching force constant $\mathrm{k}^{a}(\mathrm{~T} \cdots \mathrm{A})$ in Figure 4 . Similar to previous studies $[30,34,40,116-118,144]$, we determined the covalent character of the TB by utilizing the energy density $\mathrm{H}_{b}$ at the density critical point of the TB (Figure 5); electrostatic interactions were characterized by having positive $\mathrm{H}_{b}$ values, whereas, according to the Cremer-Kraka criterion, $[145,146]$, covalent interactions have negative $\mathrm{H}_{b}$ values, indicating that the accumulated electron density at the interactions region stabilizes the complex. Although the relationship between BSO $n$ and $\mathrm{H}_{b}$ is scattered, the TB strength tends to increase with the increasing covalent character of the interaction, especially among neutral complexes.

Table 2. Geometry, vibrational spectroscopy data, and values of the electrostatic potential for the monomers *.

\begin{tabular}{|c|c|c|c|c|c|c|c|}
\hline \# & Monomers & $\mathbf{V}_{s_{\max }}(\mathrm{X})$ & $\mathrm{r}(\mathrm{XT})$ & $\mathbf{k}^{a}(\mathrm{XT})$ & $\mathrm{n}(\mathrm{XT})$ & Dipole & $\alpha_{i s o}$ \\
\hline 36 & $\mathrm{~F}-\mathrm{CH}_{3}$ & 0.90 & 1.389 & 5.107 & 1.048 & 1.88 & 2.5 \\
\hline 37 & $\mathrm{Cl}-\mathrm{CH}_{3}$ & 0.76 & 1.792 & 3.068 & 0.786 & 1.92 & 4.3 \\
\hline 38 & $\mathrm{Br}-\mathrm{CH}_{3}$ & 0.69 & 1.948 & 2.616 & 0.718 & 1.86 & 5.4 \\
\hline 39 & $\mathrm{HO}-\mathrm{CH}_{3}$ & 0.47 & 1.426 & 4.749 & 1.006 & & 3.1 \\
\hline 40 & $\mathrm{~F}-\mathrm{CF}_{3}$ & 0.93 & 1.321 & 6.204 & 1.170 & 0.00 & 2.8 \\
\hline 41 & $\mathrm{~F}-\mathrm{SiH}_{3}$ & 1.64 & 1.613 & 5.120 & 1.049 & 1.38 & 4.1 \\
\hline 42 & $\mathrm{Cl}-\mathrm{SiH}_{3}$ & 1.51 & 2.072 & 2.799 & 0.746 & 1.41 & 6.2 \\
\hline 43 & $\mathrm{Br}-\mathrm{SiH}_{3}$ & 1.46 & 2.238 & 2.321 & 0.672 & 1.38 & 7.4 \\
\hline 44 & $\mathrm{HO}-\mathrm{SiH}_{3}$ & 1.14 & 1.664 & 4.517 & 0.978 & & 4.9 \\
\hline 45 & $\mathrm{H}-\mathrm{SiH}_{3}$ & 0.81 & 1.483 & 2.903 & 0.762 & 0.00 & 4.6 \\
\hline 46 & $\mathrm{~F}-\mathrm{SiH}_{2} \mathrm{~F}$ & 1.72 & 1.597 & 5.497 & 1.092 & & 3.5 \\
\hline $47 a$ & $\mathrm{~F}-\mathrm{SiF}_{2} \mathrm{H}$ & 1.78 & 1.583 & 5.884 & 1.135 & & 3.8 \\
\hline $47 b$ & $\mathrm{H}-\mathrm{SiF}_{3}$ & 1.44 & 1.458 & 3.273 & 0.815 & 1.43 & 3.8 \\
\hline 48 & $\mathrm{~F}-\mathrm{SiF}_{3}$ & 1.98 & 1.571 & 6.281 & 1.178 & 0.00 & 3.3 \\
\hline 49 & $\mathrm{~F}-\mathrm{GeH}_{3}$ & 1.93 & 1.793 & 4.951 & 1.030 & 2.25 & 4.7 \\
\hline 50 & $\mathrm{Cl}-\mathrm{GeH}_{3}$ & 1.66 & 2.175 & 2.491 & 0.699 & 2.04 & 6.9 \\
\hline 51 & $\mathrm{Br}-\mathrm{GeH}_{3}$ & 1.57 & 2.330 & 2.091 & 0.633 & 1.93 & 8.1 \\
\hline 52 & $\mathrm{HO}-\mathrm{GeH}_{3}$ & 1.33 & 1.802 & 3.872 & 0.896 & & 5.5 \\
\hline 53 & $\mathrm{H}-\mathrm{GeH}_{3}$ & 0.73 & 1.542 & 2.693 & 0.730 & 0.00 & 5.2 \\
\hline 54 & $\mathrm{O}=\mathrm{CO}$ & 1.18 & 1.167 & 15.613 & 1.969 & 0.00 & 2.6 \\
\hline 55 & $\mathrm{~S}=\mathrm{CO}$ & 0.64 & 1.575 & 7.227 & 1.275 & 0.68 & 5.2 \\
\hline 56 & $\mathrm{O}=\mathrm{CF}_{2}$ & 1.85 & 1.177 & 14.680 & 1.902 & 1.00 & 2.8 \\
\hline 57 & $\mathrm{~S}=\mathrm{CF}_{2}$ & 1.29 & 1.603 & 6.626 & 1.214 & 0.16 & 5.2 \\
\hline 58 & $\mathrm{O}=\mathrm{SiF}_{2}$ & 3.46 & 1.517 & 9.243 & 1.465 & 2.31 & 4.0 \\
\hline 59 & $\mathrm{CH}_{3}{ }^{+}$ & 10.01 & & & & 0.00 & 1.3 \\
\hline 60 & $\mathrm{~F}-\mathrm{NH}_{3}{ }^{+}$ & 8.58 & 1.368 & 5.642 & 1.109 & 4.78 & 1.7 \\
\hline
\end{tabular}

* Maximum electrostatic potential at the $\sigma$-hole of $\mathrm{X}\left(\mathrm{V}_{s_{\max }}(\mathrm{X})\right)$ in $\mathrm{eV}$. XT bond distance $\mathrm{r}(\mathrm{XT})$ in $\AA$, XT local stretching force $k^{a}(X T)$ in mdyn/ $\AA$, XT bond strength order $\mathrm{n}(\mathrm{XT})$. Dipole moment in Debye and static isotropic polarizability in $\AA^{3}$. All values were calculated with CCSD(T)/aug-cc-pVTZ.

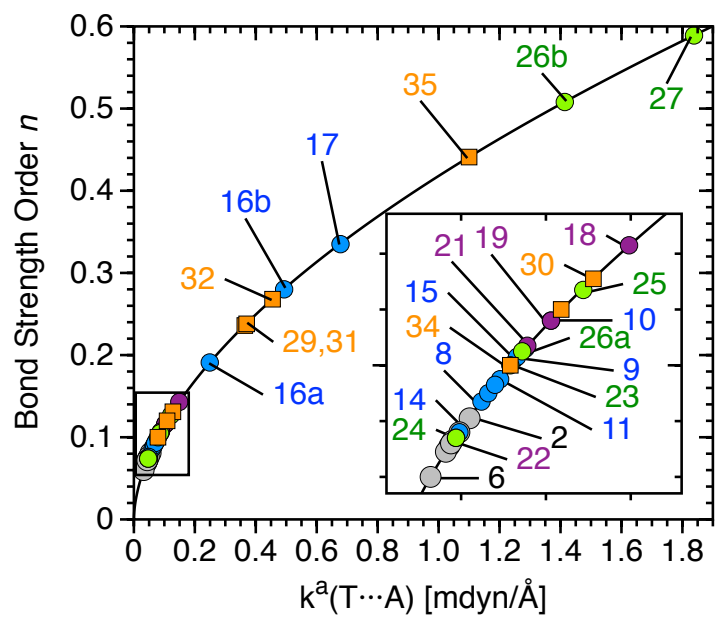

Figure 4. Power relationship between the relative bond strength order (BSO) $n$ and the local stretching force constants $k^{a}$ of the TA interaction of complexes 1-35. C donors are gray, Si donors are blue, Ge donors are purple, double bonded donors are green, and charge-assisted TBs are orange. Complex 28 is not shown. Calculated at the $\operatorname{CCSD}(\mathrm{T}) /$ aug-cc-pVTZ level of theory. 


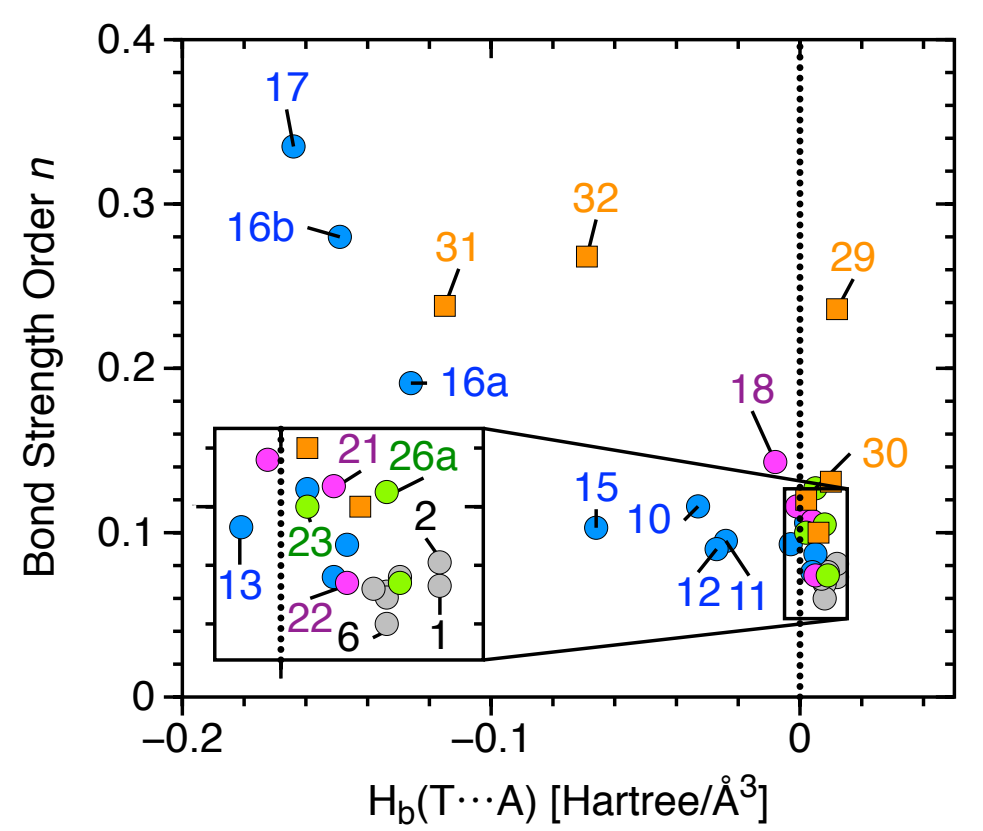

Figure 5. Comparison of the relative bond strength order (BSO) $n$ and the energy density at the bond critical point $\mathrm{H}_{b}$ of the tetrel bond of complexes. $\mathrm{C}$ tetrel bonds are gray, Si tetrel bonds are blue, Ge tetrel bonds are purple, double bonded tetrel bonds are green, and anionic tetrel bonds are orange. Complexes 26b-28 and 35 are not shown. Calculated at the CCSD(T)/aug-cc-pVTZ level of theory.

\subsection{Tetrel Bonds (TB) in Neutral Complexes}

TBs involving $C$ donors: Tetrel bonds (TBs) involving a neutral $\mathrm{sp}^{3}$ hybridized carbon as a tetrel donor and neutral tetrel acceptors (complexes 1-7) have weak interactions (BSO $n \leq 0.081 ; \Delta E \geq-2.25 \mathrm{kcal} / \mathrm{mol}$ ). The energy density at the TB density critical point is destabilizing $\left(H_{b} \geq 0.007\right.$ Hartree $\left./ \AA^{3}\right)$, indicating that these TBs are electrostatic in nature. TB with $C$ donors that have peripheral $\mathrm{H}$ ligands (1-6) are not only stabilized by a lone pair of the $\mathrm{T}$ acceptor $\mathrm{lp}(\mathrm{A})-\sigma$-hole electrostatic attraction but also by the electrostatic attraction between the positive charge at the hydrogen atoms (Hs) and the negative charge at lp(A) (see the NPA atomic charges in Figure 2 and the monomers' electrostatic potential in Table 2 and Figure 3). The presence of the later interactions were also verified by noncovalent interaction plots (NCIs plots), which showed a weak (attractive) electrostatic interaction (see Supporting Information Figure S2). Complex $7\left(\mathrm{CF}_{4} \cdots \mathrm{NH}_{3}\right)$ shows that an attractive interaction can be formed even in the absence of positively charged Hs on the T-donor. However, in 7, there is no electron density path connecting the $\mathrm{N}$ of the $\mathrm{T}$ acceptor to the $\mathrm{C}$ of the $\mathrm{T}$ donor indicating the formation of a very weak dispersive interaction, as pointed by Grabowski [147]. The calculated spectra of 7 clearly shows an intermonomer stretching vibration of $A_{1}$ symmetry at $73 \mathrm{~cm}^{-1}$. Decomposition of the normal vibrational mode into the local vibrational mode shows that the $\mathrm{CN}$ local stretching mode contributes solely to this normal vibrational mode, confirming the existence of tetrel bonding in 7 . As revealed by the NCI plot analysis, the peripheral $\mathrm{H}$ ligands of the T acceptor have an additional weak (attractive) electrostatic interaction with the peripheral $\mathrm{F}$ ligands of the $\mathrm{T}$ donor, which provides additional stabilization to the complex (see Supporting Information Figure S2).

The TB strength in the series of $C$ donors and neutral $T$ acceptors (1-7) shows only a small variation $(0.021$ for $n$ and $0.87 \mathrm{kcal} / \mathrm{mol}$ for $\Delta E)$ which is affected by several factors such as the positive charge at the $\mathrm{Hs}(5>\mathbf{4}>\mathbf{3} \approx 6)$, the negative electrostatic potential at $\mathrm{lp}(\mathrm{A})$ of the T-acceptor $\left(\mathrm{NH}_{3}<\mathrm{OH}_{2}<\mathrm{FH}\right)$, and the intermonomer distance (e.g., $3.035 \AA$ (2) compared to 3.218 (3)). It is noteworthy that for $\mathrm{X}-\mathrm{CH}_{3} \cdots \mathrm{NH}_{3}$ complexes, the TB strength weakens in the order of $3(\mathrm{X}=\mathrm{F})>4(\mathrm{X}$ $=\mathrm{Cl})>5(\mathrm{X}=\mathrm{Br})>6(\mathrm{X}=\mathrm{OH})$ as the magnitude of the $\sigma$-hole decreases $\left(36\left(\mathrm{~F}-\mathrm{CH}_{3}\right)\right)>37\left(\mathrm{Cl}-\mathrm{CH}_{3}\right)$ $>38\left(\mathrm{Br}-\mathrm{CH}_{3}\right)>39\left(\mathrm{OH}-\mathrm{CH}_{3}\right)$ (see Figure 3$)$. 
TB involving Si donors: The strength of complexes 8-14 can be understood mostly on the basis of the extreme values of the electrostatic potential of the monomers. First, by varying the T-acceptor in $\mathrm{FSiH}_{3} \cdots \mathrm{A}$, where $\mathrm{A}=\mathrm{FH}(\mathbf{8}), \mathrm{OH}_{2}(\mathbf{9}), \mathrm{NH}_{3}(\mathbf{1 0})$, the TB strength trends follows the increase in magnitude of the negative potential at the $\mathrm{lp}(\mathrm{A})$ of the Lewis base. It is noticeable that $V_{s, \min }(\mathrm{A})$ and $V_{s, \max }(\mathrm{T})$ in 9 are not aligned as in $\mathbf{2}$, indicating that even in this case, the stabilization brought by electron delocalization involving the highest occupied orbital $\mathrm{HOMO}$ of $\mathrm{H}_{2} \mathrm{O}$ (the $\mathrm{lp}(\mathrm{O})$ orbital of $\mathrm{B}_{1}$ symmetry, see Supporting Information Figure S3) and the lowest unoccupied orbital of $\mathrm{FSiH}_{3}$ $\left(\sigma^{\star}(\mathrm{SiF})\right.$ orbital) can influence the geometry of the complex (see Supporting Information Figure S4). Second, by varying the $\mathrm{T}$ donors in the $\mathrm{XSiH}_{3} \cdots \mathrm{NH}_{3}$ complexes, the TB strength decreases in the order $10(\mathrm{X}=\mathrm{F})>11(\mathrm{X}=\mathrm{Cl})>12(\mathrm{X}=\mathrm{Br}) \approx 13(\mathrm{X}=\mathrm{OH})>14(\mathrm{X}=\mathrm{H})$ as the Vs at the $\sigma$-hole decreases $(41$ $\left.\left(\mathrm{F}-\mathrm{SiH}_{3}\right)>42\left(\mathrm{Cl}-\mathrm{SiH}_{3}\right)>43\left(\mathrm{Br}-\mathrm{SiH}_{3}\right)>44\left(\mathrm{HO}-\mathrm{SiH}_{3}\right)>45\left(\mathrm{SiH}_{4}\right)\right)$. The only exception is 44 , which has a more positive NBO charge at $\mathrm{Si}$ (1277 me compared to 852 me in 43) but a less positive $V_{s, \max }(1.14$ (44) compared to 1.46 (43), see Table 2 and Supporting Information Figure S1). This could be caused by the stronger $\sigma(\mathrm{O}-\mathrm{Si})$ orbital contraction, whereby the $\mathrm{Si}$ atom in $\mathrm{HOSiH}_{3}$ is more electron-deficient than the $\mathrm{Si}$ atom in $\mathrm{BrSiH}_{3}$, but due to the higher electronegativity of $\mathrm{O}$, the $\sigma(\mathrm{O}-\mathrm{Si})$ is more compact than $\sigma(\mathrm{Br}-\mathrm{Si})$, resulting in a better shielded $\mathrm{Si}$ nucleus, reflected in the less positive potential at the $\sigma$-hole region (given by $V_{s, \max }$ ). Substituting $\mathrm{F}$ in $\mathrm{FSiH}_{3}$ would lead to an even stronger $\sigma(\mathrm{F}-\mathrm{Si}$ ) orbital contraction, but this effect would be overcome by the higher electron deficiency of $\mathrm{Si}$.

Stepwise fluorination of $\mathrm{SiH}_{4}$ : The successive fluorination of $\mathrm{SiH}_{4}$ (complexes 10 and 15-17) impacts both the strength and the nature of the TB. Substituting the $\mathrm{H}$ collinear to the TB in complex 14 results in complex 10, which has a stronger TB interaction due to the higher $\mathrm{V}_{s}$ at the $\sigma$-hole region and is due to the partial covalent character of the interaction $\left(\mathrm{H}_{b}=-0.033\right.$ Hartree $/ \AA$ for complex 10), which can be understood on the basis of molecular orbital interactions, as the electron delocalization from the highest occupied molecular orbital (HOMO) of the $\mathrm{NH}_{3}$ (lone pair orbital of $\mathrm{N}, \mathrm{lp}(\mathrm{N})$ ) into the lowest unoccupied molecular orbital (LUMO) of $\mathrm{FSiH}_{3}\left(\mathrm{a} \sigma^{\star}(\mathrm{FSi})\right.$ orbital see Supporting Information Figure S5).

A second fluorine substituent (complex 15) shows three different electronic effects: (i) the second fluorine withdraws the electron density from $\mathrm{Si}$, decreasing its covalent radius and thus increasing the $\mathrm{V}_{S}$ at the $\sigma$-hole region, resulting in a stronger $\sigma$-hole-lp(N) electrostatic attraction; (ii) the $\operatorname{lp}(\mathrm{N}) \rightarrow$ $\sigma^{\star}(\mathrm{SiF})$ electron delocalization is not restricted to the $\sigma^{\star}$ orbital of the $\mathrm{Si}-\mathrm{F}$ bond that is collinear to the $\operatorname{lp}(\mathrm{A})$ but can also take place to the $\sigma^{\star}$ orbital of the second Si-F bond (see Table 3); (iii) the orbital effect of the exchange-repulsion between the lone pair orbitals of the peripheral fluorine $l p(F)$ and $l p(N)$ orbital. Effects (i) and (ii) are responsible for the $0.123 \AA$ shorter TB in $\mathbf{1 5}$ compared to $\mathbf{1 0}$. However, due to effect (iii), complexes 10 and 15 have similar TB strengths ( $n=0.116$ for 10, 0.103 for 15; $\Delta \mathrm{E}=$ $6.8 \mathrm{kcal} / \mathrm{mol}$ for 10 , and $7.0 \mathrm{kcal} / \mathrm{mol}$ for 15$)$.

The addition of a third fluorine substituent (complexes 16a and 16b) leads to shorter and stronger TBs (BSO $n=0.191$ (16a) and 0.280 (16b) compared to 0.103 (15)). However, this great increase in the TB strength (especially for $16 \mathrm{~b}$ ) is not reflected by the binding energies of $16 \mathrm{a}$ and $16 \mathrm{~b}(\Delta \mathrm{E}=-7.7 \mathrm{kcal} / \mathrm{mol}$ for $16 \mathrm{a}$ and $-6.3 \mathrm{kcal} / \mathrm{mol}$ for $\mathbf{1 6 b}$ ). The reason for the unexpectedly low $\Delta \mathrm{E}$ values of $16 \mathrm{a}$ and $\mathbf{1 6} \mathbf{b}$ is due to the energetic cost associated with the geometric deformation of the monomers upon complexation $\left(\mathrm{E}_{\text {def }}=11.8 \mathrm{kcal} / \mathrm{mol}\right.$ for $16 \mathrm{a}, 21.2 \mathrm{kcal} / \mathrm{mol}$ for $\left.\mathbf{1 6 b}\right)$. Monomer deformation is mostly caused by the $\operatorname{lp}(\mathrm{F})-\mathrm{lp}(\mathrm{N})$ exchange-repulsion (effect (iii)), which pushes the peripheral ligands towards the bond collinear to the TB. For example, there is a decrease of $12.3^{\circ}$ in the $\mathrm{H}-\mathrm{Si}-\mathrm{F}$ bond angle of $\mathrm{HSiF}_{3}$ upon the formation of $\mathbf{1 6 b}$. Monomer deformation and the steric effect on TB complexes were also topics of a recent study carried by Scheiner $[148,149]$. It is noteworthy that the strongest TB between $\mathrm{SiF}_{3} \mathrm{H}$ and $\mathrm{NH}_{3}$ is collinear to the $\mathrm{V}_{s}$ at the $\sigma$-hole of the Si-H bond (complex 16b), instead of the most positive potential at the $\sigma$-hole of the $\mathrm{Si}-\mathrm{F}$ bond as one would expect from the $\sigma$-hole model or from steric considerations. The stronger and more covalent bond in $\mathbf{1 6 \mathbf { b }}$ is due to the higher stabilization energies brought by electron delocalization from $\operatorname{lp}(\mathrm{N})$ into $\sigma^{\star}(\mathrm{FSi})$ and into the $\sigma^{\star}(\mathrm{HSi})$ unoccupied 
orbital, as shown in Table 3. Even if the TB of $\mathbf{1 6 b}$ is elongated to match the TB distance of $\mathbf{1 6 a}$, the NBO second-order delocalization energies of $\mathbf{1 6} \mathbf{b}$ are still higher than those of $\mathbf{1 6} \mathbf{a}$ (see Table 3).

Table 3. Naural Bond Orbital (NBO) electron delocalization energies involving the lone pair of $\mathrm{NH}_{3}$ *.

\begin{tabular}{llrrrr}
\hline$\#$ & Complex & $\sigma^{\star}(\mathbf{X}-\mathbf{S i})$ & $\sigma^{\star}(\mathbf{S i}-\mathbf{R})$ & $\sigma^{\star}\left(\mathbf{S i}-R^{\prime}\right)$ & $\sigma^{\star}\left(\mathbf{S i}-R^{\prime \prime}\right)$ \\
\hline $\mathbf{1 0}$ & $\mathrm{FSiH}_{3} \cdots \mathrm{NH}_{3}$ & 15.7 & 2.4 & 2.4 & 2.4 \\
$\mathbf{1 5}$ & $\mathrm{SiF}_{2} \mathrm{H}_{2} \cdots \mathrm{NH}_{3}$ & 12.7 & 6.2 & 3.1 & 3.1 \\
$\mathbf{1 6 a}$ & $\mathrm{SiF}_{3} \mathrm{H} \cdots \mathrm{NH}_{3}$ & 16.3 & 11.9 & 11.9 & 7.5 \\
$\mathbf{1 6 b}$ & $\mathrm{SiF}_{3} \mathrm{H} \cdots \mathrm{NH}_{3}$ & 11.4 & 23.5 & 23.5 & 23.5 \\
$\mathbf{1 6 b}$ & $\mathrm{SiHF}_{3} \cdots \mathrm{NH}_{3}$ & 7.9 & 16.8 & 16.8 & 16.8 \\
$\mathbf{1 7}$ & $\mathrm{SiF}_{4} \cdots \mathrm{NH}_{3}$ & 20.7 & 19.5 & 19.5 & 19.5 \\
\hline
\end{tabular}

* NBO electron delocalization energies from the second-order perturbation analysis referent to the interaction involving the $\mathrm{lp}(\mathrm{N})$ orbital of $\mathrm{NH}_{3}$ and the $\sigma^{\star}(\mathrm{X}-\mathrm{Si})$ (collinear to the $\left.\mathrm{TB}\right)$, the $\sigma^{\star}(\mathrm{Si}-\mathrm{R}), \sigma^{\star}\left(\mathrm{Si}-\mathrm{R}^{\prime}\right)$ and the $\sigma^{\star}\left(\mathrm{Si}-\mathrm{R}^{\prime \prime}\right)$ (peripheral to the TB, see Figure 1) of selected tetrel donors (see Supporting Information Figure S5). Values are in $\mathrm{kcal} / \mathrm{mol}$. Calculated with $\omega \mathrm{B} 97 \mathrm{XD} /$ aug-cc-pVTZ. ${ }^{\text {a }}$ Complex 16b with an elongated tetrel bond (TB) to match the TB distance of $\mathbf{1 6 a}$.

The addition of a fourth fluorine (complex 17) makes the TB even stronger ( $n=0.335$ for 17), compared to 0.280 for 16), which is a consequence of the more positive $V_{s}$ and of the higher electron delocalization that occurs from $\mathrm{lp}(\mathrm{N})$ to $\sigma^{\star}(\mathrm{FSi})$ compared to $\sigma^{\star}(\mathrm{H}-\mathrm{Si})$ (see Table 3 and Supporting Information Figure S5). The substitution of the $\mathrm{H}$ collinear to the TB in $\mathbf{1 6} \mathbf{b}$ by a fluorine does not increase the steric repulsion between the monomer $\left(\mathrm{E}_{\text {def }}\right.$ of $\mathbf{1 7}$ is almost the same of $\mathbf{1 6 b}$ ), and as a result, $\Delta \mathrm{E}$ is $5.1 \mathrm{kcal} / \mathrm{mol}$ more stable.

TB involving Ge donors: The germanium electron density is more easily polarized by an electronegative substituent than silicon. As a result, $\mathrm{V}_{s}$ at the $\sigma$-hole of Ge-donors (49-52) are higher than Si donors (see Table 2), the only exception being $\mathrm{GeH}_{4}$ (53), which is a consequence of the higher electronegativity of $\mathrm{Ge}(\chi(\mathrm{Si}): 1.74$ compared to $\chi(\mathrm{Ge}): 2.02)$. Due to the stronger $\operatorname{lp}(\mathrm{N})-\sigma$-hole electrostatic attraction, mono-substituted Ge-donors $(18,19,20,21)$ form stronger TBs than mono-substituted $\mathrm{Si}$ donors $(\mathbf{1 0}, \mathbf{1 1}, \mathbf{1 2}, \mathbf{1 3})$ when paired with the $\mathrm{NH}_{3} \mathrm{~T}$ acceptor. Conversely, the covalent component of this interaction is slightly reduced because of the more diffuse nature of $\mathrm{Ge}$ orbitals (see $\mathrm{CT}$ and $\mathrm{H}_{b}$ values on Table 1). Similar to $\mathrm{C}$ donors and $\mathrm{Si}$ donors, for $\mathrm{X}-\mathrm{GeH}_{3} \cdots \mathrm{NH}_{3}$ complexes, the TB strength decreases in the order of $\mathbf{1 8}(\mathrm{X}=\mathrm{F})>\mathbf{1 9}(\mathrm{X}=\mathrm{Cl})$ $>20(\mathrm{X}=\mathrm{Br})>21(\mathrm{X}=\mathrm{OH})$, as the magnitude of the $\sigma$-hole decreases $\left(49\left(\mathrm{~F}-\mathrm{GeH}_{3}\right)\right)>50\left(\mathrm{Cl}-\mathrm{GeH}_{3}\right)$ $>\mathbf{5 1}\left(\mathrm{Br}-\mathrm{GeH}_{3}\right)>\mathbf{5 2}\left(\mathrm{OH}-\mathrm{GeH}_{3}\right)$ (see Table 2 and Figure 3).

TB in double bonded $\mathrm{C}$ and Si donors: When a carbon atom forms a $\pi$-bond, density is moved from a p-orbital of the carbon into the $\pi$-bond, resulting in a depletion of electron density at the $C$ and the formation of a region of positive potential called a $\pi$-hole $[150,151]$. As noted previously by various authors [152-154], the $\operatorname{lp}(\mathrm{A})-\pi$-hole electrostatic attraction is an important component of the TB involving double bonded C, Si donors. Another important characteristic of these T-donors is the existence of a low lying empty $\pi^{\star}(\mathrm{XT})$ orbital which is capable of accepting electron density from the $\operatorname{lp}(\mathrm{A})$ orbital of the T-acceptor. In order to evaluate strategies to strengthen TB involving double bonded $\mathrm{C}$ and $\mathrm{Si}$ donors, complexes 23-27 were investigated. Due to the $\mathrm{D}_{\infty h}$ and $\mathrm{C}_{\infty v}$ symmetry of $\mathrm{CO}_{2}(54)$ and $\mathrm{SCO}(55)$, respectively, the $\pi$-bond density of these monomers has a central constriction with a negative $\mathrm{V}_{S}$, leaving a belt-shaped $\pi$-hole around the $\mathrm{C}$ atom (see Figure 3). In SCO (55), a chalcogen bond is also possible due to the formation of a positive $\mathrm{V}_{S}$ at the $\sigma$-hole of sulfur. The TBs between $\mathrm{CO}_{2}(23)$ and $\mathrm{SCO}(24) \mathrm{T}$ donors and the prototypical T acceptor $\mathrm{NH}_{3}$ are weak $(n=0.100$ (23), 0.074 (24)) and electrostatic in nature $\left(\mathrm{H}_{b}>0.002\right.$ Hartree $\left./ \AA\right)$.

Substituting a $\mathrm{CO}$ double bond by two $\mathrm{CF}$ single bonds in $\mathbf{2 3}$ and $\mathbf{2 4}$ results in complexes $\mathrm{CF}_{2} \mathrm{O} \cdots \mathrm{NH}_{3}$ (25) and $\mathrm{CF}_{2} \mathrm{~S} \cdots \mathrm{NH}_{3}(26)$, respectively. The T-donors of these complexes are characterized by having a higher $\mathrm{V}_{s}$ at the $\pi$-hole $\left(\mathrm{V}_{s}=1.85 \mathrm{eV}(56), 1.29 \mathrm{eV}(57)\right.$ compared to $1.18 \mathrm{eV}(54)$ and $0.64 \mathrm{eV}(55))$, resulting in stronger TBs $(n=0.127$ (25), 0.105 (26a) compared to 0.100 (23) and $0.074(\mathbf{2 4}))$. The atypically strong $(n=0.508)$, highly covalent $\left(\mathrm{H}_{b}=-1.339\right.$ Hartree $\left./ \AA^{3}\right)$ and short interactions 
$(\mathrm{r}(\mathrm{TA})=1.7 \AA)$ found in complex $\mathbf{2 6} \mathbf{b}$ are formed at the expense of breaking the $\mathrm{CS} \pi$-bond $(n(\mathrm{C}=\mathrm{S})$ decreases from 1.214 in 57 to 0.891 in $\mathbf{2 6 b}$ ). The energetic cost involved in the deformation of the monomers of $\mathbf{2 6 b}$ is $1.45 \mathrm{kcal} / \mathrm{mol}$ higher than the stabilization brought by complexation $\left(\mathrm{E}_{\text {int }}\right)$; hence, the $\mathbf{2 6} \mathbf{b}$ is less stable than the separated monomers. A small energetic barrier in the dissociative direction separates $\mathbf{2 6 b}$ from the electrostatic TB complex 26a (see Figure 6). An even stronger ( $n=0.589)$ but less covalent interaction $\left(\mathrm{H}_{b}=-0.224\right.$ Hartree $\left./ \AA^{3}\right)$ is formed between $\mathrm{SiF}_{2} \mathrm{O}$ and $\mathrm{NH}_{3}$ (complex 27). In this complex, the $\mathrm{SiO}$ double bond is kept almost unaltered ( $n=1.465(58) ; 1.425(27)$ ); consequently, the deformation energy is relatively low compared to the stabilization energy brought by the complexation, resulting in a binding energy of $-44.14 \mathrm{kcal} / \mathrm{mol}$.

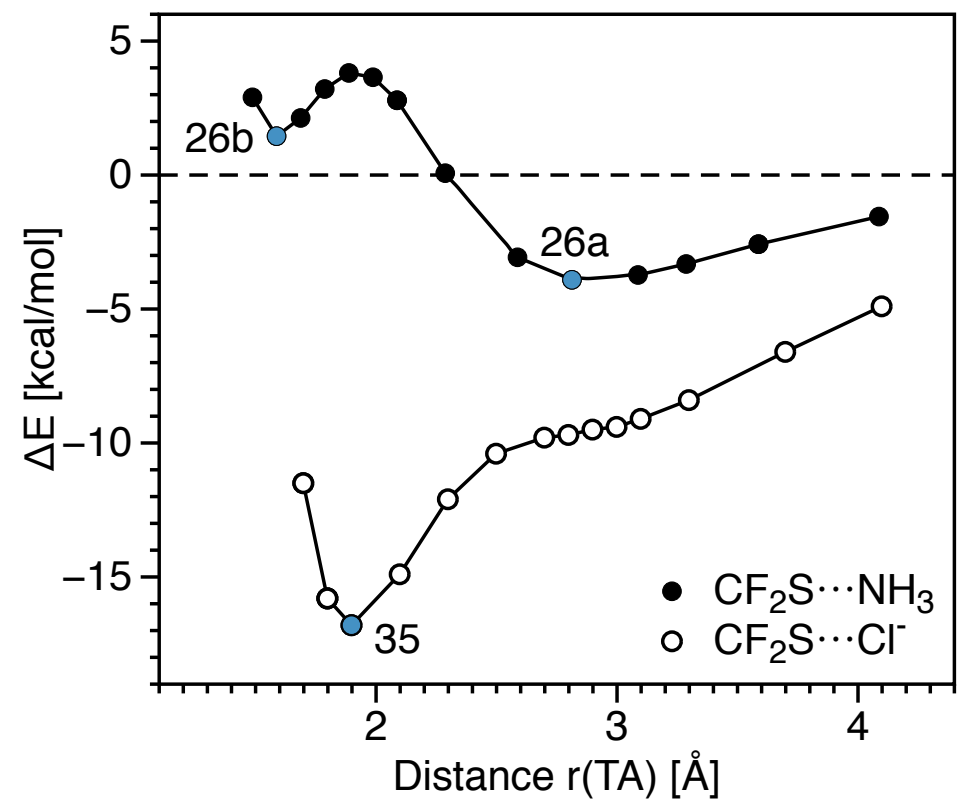

Figure 6. Relationship between the binding energy and interactomic distance computed at the $\operatorname{CCSD}(\mathrm{T})$ /aug-cc-pVTZ level of theory. All geometric parameters were optimized at each point of the curves for fixed r(TA) values. The blue dots represent the binding energy at the minima of complex 26 and the minimum of 35 ; the black lines connecting points were used to improve interpretation.

\subsection{Charge-Assisted Tetrel Bonds}

Charge-assisted interactions: Similar to other NCIs [30,34,116,118,155], TBs can be strengthened by having a positively-charged $\mathrm{T}$ donor or a negatively-charged $\mathrm{T}$ acceptor $\mathbf{3 0}-\mathbf{3 5}$. The simplest positively charged $\mathrm{C}$ donor is $\mathrm{CH}_{3}{ }^{+}$(isoelectronic to $\mathrm{BH}_{3}$ ). However, due to the availability of an empty $p$-orbital to coordinate with the lone pairs of the $\mathrm{NH}_{3}$, the $\mathrm{C}-\mathrm{N}$ bond in 28 clearly differs from the tetrel bonds. This covalent bond in $\left[\mathrm{CH}_{3}-\mathrm{NH}_{3}\right]^{+}(28)$ is much stronger $(n=0.882 ; \Delta \mathrm{E}=$ $-110.26 \mathrm{kcal} / \mathrm{mol})$ and covalent $\left(\mathrm{H}_{b}=-1.952\right.$ Hartree $\left./ \AA^{3}\right)$ compared to a TB. The existence of a covalent bond in complex $\mathbf{2 8}$ is also confirmed by the NCI plot, showing that there is no noncovalent interaction (see Supporting Information Figure S2). On the other hand, the cationic pnicogen donor $\mathrm{FNH}_{3}{ }^{+}$, isoelectronic to $\mathrm{FCH}_{3}$, forms a noncovalent interaction with the $\mathrm{NH}_{3}$ (complex 29) which closely resembles the ones formed by neutral $C$ donors (1-7) characterized by an electrostatic nature $\left(\mathrm{H}_{b}\right)$ and an interaction collinear to the $\mathrm{X}$-T bond. The only difference is the higher $\mathrm{V}_{s}$ at the $\sigma$-hole $\left(\mathrm{V}_{s}\right.$ $=8.58 \mathrm{eV})$, which results in a stronger electrostatic interaction $(n=0.236 ; \Delta \mathrm{E}=-23.14 \mathrm{kcal} / \mathrm{mol})$.

An increase in the TB strength of as much as 105\% (31) occurs for complexes involving a neutral T donor and a chloride anion as a $\mathrm{T}$ acceptor. This increase does not affect $\mathrm{TB}$ strength trends, such as $\mathrm{FGeH}_{3}>\mathrm{FSiH}_{3}>\mathrm{FCH}_{3}$, and $\mathrm{CO}_{2}>\mathrm{SCO}$, nor the trends in the covalent character of the TB in these series. Conversely, complex $\mathrm{CF}_{2} \mathrm{~S}$ forms a weaker bond with $\mathrm{Cl}^{-}$compared to $\mathrm{NH}_{3}(n=0.441$ (35) $0.508(\mathbf{2 6 b}))$, but has a highly negative binding energy $(\Delta \mathrm{E}=-16.81 \mathrm{kcal} / \mathrm{mol}$ of $35 \mathrm{compared}$ to the 
$1.45 \mathrm{kcal} / \mathrm{mol}$ of $\mathbf{2 6 b}$ ). The inverse relationships between the bond strength and interaction energies $\left(\mathrm{E}_{\text {int }}\right)$ or binding energies $(\Delta \mathrm{E})$ between these complexes indicate that the local $\mathrm{C}-\mathrm{N}$ or $\mathrm{C}-\mathrm{Cl}$ stretching is not the determining factor for the complex stabilization. Other components of the interaction which do not contribute to the strength of T-A local stretching also stabilize the complex. Figure 6 shows the dissociation curves for the $\mathrm{CF}_{2} \mathrm{~S} \cdots \mathrm{NH}_{3}(26)$ and $\mathrm{CF}_{2} \mathrm{~S} \cdots \mathrm{Cl}^{-}$(35). Only 26 has a minimum geometry with an electrostatic TB (26a), whereas the dissociation curve for 35 has a flat region around $\mathrm{r}(\mathrm{TA})=$ 2.9 $\AA$ separating the electrostatic interaction found for long TBs from the strong covalent interactions in 35. The barrier energy from $\mathbf{2 6 a}$ to $\mathbf{2 6 b}$ is about $3 \mathrm{kcal} / \mathrm{mol}$.

\subsection{Tetrel Bonds vs. Other Noncovalent Interactions}

We also compared TB with other noncovalent interactions, such as halogen (XB), chalcogen (ChB), and pnicogen (PnB), in mono-fluorinated systems involving the third period series $\mathrm{FCl}, \mathrm{FSH}, \mathrm{FPH}_{2}$ with a medium $\left(\mathrm{OH}_{2}\right)$ and a strong $\left(\mathrm{NH}_{3}\right)$ Lewis base (see Table 4$)$. It was clearly shown that the TB formed by $\mathrm{FSiH}_{3}$ tend to be weaker than the other noncovalent interactions, the only exception being $\mathrm{FSiH}_{3} \cdots \mathrm{Cl}^{-}(31)(n=0.238)$ which is slightly stronger than $\mathrm{FPH}_{2} \cdots \mathrm{Cl}^{-}(n=0.214)$ but weaker than FSH $\cdots \mathrm{Cl}^{-}(n=0.264)$ and $\mathrm{FCl} \cdots \mathrm{Cl}^{-}(n=0.382)$. Increasing the polarizability of the $\mathrm{T}$ donor moving $\mathrm{FSiH}_{3}$ to $\mathrm{FGeH}_{3}$ does increase the strength of the tetrel bond enough to compete with the halogen bonds formed by FCl. A better strategy for obtaining TBs that are strong enough to compete with halogen bonds and other noncovalent interactions is the substitution of peripheral $\mathrm{Hs}$ in $\mathrm{FSiH}_{3}$ by fluorine atoms. $\mathrm{SiF}_{4} \cdots \mathrm{NH}_{3}(\mathbf{1 7})$, for example, has a $\mathrm{BSO}$ of $n=0.335$ compared to $n=0.216$ for the $\mathrm{FCl} \cdots \mathrm{NH}_{3}$. A clear advantage of tetrel bonding is that even in the absence of a strong polarizing group collinear to the $\mathrm{TB}$, such as in $\mathrm{HSiF}_{3} \cdots \mathrm{NH}_{3}$, the $\mathrm{TB}$ is still stronger than other noncovalent interactions $(n=0.280$ for $\mathbf{1 6 b})$. This TB feature should be extensively explored to tune the strength of TB involving not only Si donors but also the heavier and more polarizable Ge and Sn donors.

Table 4. Summary of energetics, geometric and vibrational spectroscopy data for other types of interactions *.

\begin{tabular}{|c|c|c|c|c|c|c|c|c|c|c|}
\hline Complex & $\Delta E$ & $\Delta E_{c p}$ & $\begin{array}{c}\mathbf{r} \\
\mathrm{TA}\end{array}$ & CT & $\begin{array}{c}\rho \\
\text { TA }\end{array}$ & $\begin{array}{l}H_{b} \\
\text { TA }\end{array}$ & $\begin{array}{l}k^{a} \\
\text { TA }\end{array}$ & $\begin{array}{c}\mathbf{n} \\
\text { TA }\end{array}$ & $\begin{array}{l}k^{a} \\
\mathrm{XT}\end{array}$ & $\begin{array}{c}\mathbf{n} \\
\mathbf{X T}\end{array}$ \\
\hline $\mathrm{F}_{2} \cdots \mathrm{OH}_{2}\left(\mathrm{C}_{s}\right)$ & -1.42 & -1.15 & 2.662 & 0.005 & 0.066 & 0.022 & 0.057 & 0.083 & 4.488 & 0.974 \\
\hline $\mathrm{Cl}_{2} \cdots \mathrm{OH}_{2}\left(\mathrm{C}_{\mathrm{s}}\right)$ & -2.98 & -2.62 & 2.808 & 0.015 & 0.098 & 0.018 & 0.097 & 0.112 & 2.896 & 0.761 \\
\hline $\mathrm{FCl} \cdots \mathrm{OH}_{2}\left(\mathrm{C}_{s}\right)$ & -5.22 & -4.75 & 2.566 & 0.032 & 0.163 & 0.016 & 0.170 & 0.154 & 3.967 & 0.909 \\
\hline $\mathrm{FSH} \cdots \mathrm{OH}_{2}\left(\mathrm{C}_{s}\right)$ & -5.69 & -5.15 & 2.659 & 0.028 & 0.138 & 0.010 & 0.152 & 0.144 & 4.011 & 0.914 \\
\hline $\mathrm{F}_{2} \cdots \mathrm{NH}_{3}\left(\mathrm{C}_{3 v}\right)$ & -2.00 & -1.69 & 2.615 & 0.017 & 0.097 & 0.027 & 0.062 & 0.087 & 3.821 & 0.890 \\
\hline $\mathrm{Cl}_{2} \cdots \mathrm{NH}_{3}\left(\mathrm{C}_{3 v}\right)$ & -4.92 & -4.43 & 2.664 & 0.055 & 0.172 & 0.006 & 0.132 & 0.133 & 2.370 & 0.680 \\
\hline $\mathrm{FCl} \cdots \mathrm{NH}_{3}\left(\mathrm{C}_{3 v}\right)$ & -10.13 & -9.39 & 2.320 & 0.145 & 0.358 & -0.058 & 0.311 & 0.216 & 2.687 & 0.729 \\
\hline $\mathrm{FSH}_{\cdots} \cdots \mathrm{NH}_{3}\left(\mathrm{C}_{s}\right)$ & -8.23 & -7.58 & 2.512 & 0.081 & 0.235 & -0.020 & 0.194 & 0.166 & 3.309 & 0.820 \\
\hline $\mathrm{FPH}_{2} \cdots \mathrm{NH}_{3}\left(\mathrm{C}_{s}\right)$ & -6.81 & -6.10 & 2.663 & 0.057 & 0.171 & -0.012 & 0.144 & 0.140 & 3.794 & 0.886 \\
\hline
\end{tabular}

${ }^{*}$ Binding energies $(\Delta \mathrm{E})$ and conterpoise corrected binding energies $\Delta \mathrm{E}_{c p}$ in $\mathrm{kcal} / \mathrm{mol}$. Intermonomer bond distance $\mathrm{r}(\mathrm{TA})$ in $\AA$. Density at the TA critical point $\rho_{b}$ in e/ $\AA^{3}$, energy density at the TA critical point $\mathrm{H}_{b}$ in Hartree $/ \AA^{3}$. NPA charge transfer $(C T)$ in e. TA and XT local stretching force constant $\left(\mathrm{k}^{a}\right)$ in mdyn $/ \AA$ and $\mathrm{BSO} n$ values. Computed at the CCSD(T)/aug-cc-pVTZ level of theory.

\section{Conclusions}

In the present work, we investigated a set of 35 representative tetrel complexes $(\Delta \mathrm{E}=-1.4$ to $-26 \mathrm{kcal} / \mathrm{mol}$ ) with the objective of finding the factors that influence the strengths of neutral and charged tetrel bonds involving C donors, Si donors, Ge donors, and double bonded C or Si donors. The strength of a tetrel bond is affected by the complex interplay of several factors, such as the magnitude of the $\sigma$-hole in the tetrel atom, the negative electrostatic potential at the $\operatorname{lp}(\mathrm{A})$ of the $\mathrm{T}$ 
acceptors, the positive charge at the peripheral hydrogen (Hs) of the T donors, exchange-repulsion between the lone pair orbitals of the peripheral atoms of the $\mathrm{T}$ donor, and the covalent character which can be rationalized on the basis of electron delocalization from the highest occupied molecular orbital (HOMO) of the T acceptor into the lowest unoccupied orbitals (LUMOs) of the T donor, which is not limited to $\sigma^{\star}(\mathrm{X}-\mathrm{T})$ orbital but can also involve the peripheral substituents (orbital of $\sigma^{\star}(\mathrm{R}-\mathrm{Si}$ ) character), allowing the formation of strong tetrel bonds, even in the absence of an electronegative $X$ substituent collinear to the TB. This clearly shows that focusing on just one or two of these factors, in particular, the $\sigma$-hole description, can only lead to an incomplete picture $[93,94,156,157]$. In this work, we derived, for the first time, the intrinsic bond strength of tetrel bonds from calculated vibrational spectroscopy data, which, combined with NBO charges, charge transfer, dipole moments, electrostatic potentials, electron and energy density distributions, difference density distributions, and noncovalent interaction plots calculated at the CCSD(T)/aug-cc-pVTZ level of theory, led to a complete insight into how different electronic effects influence the intrinsic strength of the tetrel bonding.

- Tetrel bonding becomes stronger as the atomic mass of the tetrel center increases as a consequence of increasing the polarizability.

- $\quad$ For $X-\mathrm{TH}_{3} \cdots \mathrm{NH}_{3}$ complexes, the tetrel bond strength weakens in the order $(\mathrm{X}=\mathrm{F})>(\mathrm{X}=\mathrm{Cl})>$ $(\mathrm{X}=\mathrm{Br}) \geq(\mathrm{X}=\mathrm{OH})$ as the magnitude of the $\sigma$-hole decreases in the order of $\mathrm{F}-\mathrm{TH}_{3}>\mathrm{Cl}-\mathrm{TH}_{3}>$ $\mathrm{Br}-\mathrm{TH}_{3} \geq \mathrm{OH}-\mathrm{TH}_{3}$.

- Successive fluorination of $\mathrm{SiH}_{4}$ impacts both the strength and the nature of the tetrel bond. The successive fluorinations result in stronger tetrel bonding as a consequence of (i) higher $\mathrm{V}_{S}$ at the $\sigma$-hole region; (ii) the partial covalent character of the interaction; (iii) higher electron delocalization that occurs from the highest occupied molecular orbital (HOMO) of the $\mathrm{T}$ acceptor to the lowest unoccupied molecular orbital (LUMO) of the T donor. In this series, the binding energy trend deviates from BSO $n$ values due to the high energetic cost associated with the geometric deformation of the monomers upon complexation $\left(\mathrm{E}_{d e f}\right)$ which is a consequence of the exchange-repulsion between the lone pair orbitals of the peripheral atoms of the $\mathrm{T}$ donor.

- Tetrel bonds in double bonded $\mathrm{C}$ donors, e.g., $\mathrm{CO}_{2}$ with $\mathrm{NH}_{3}$, are weak and electrostatic in nature. Substituting a $\mathrm{C}=\mathrm{O}$ double bond with an electron withdrawing group ( $\mathrm{F}$ atoms) strengthens the tetrel bond.

- A positively-charged Tdonor or negatively-charged T-acceptor strengthens the tetrel bond. It creates higher $\mathrm{V}_{s}$ at the $\sigma$-hole, resulting in a stronger electrostatic interaction.

We suggest that future materials based on strong tetrel bonding should be based on $\mathrm{Si}$ or heavier tetrel atoms, such as Ge and Sn, combined with peripheral fluorine ligands. Due to the larger size of Ge and $\mathrm{Sn}$, the deformation energy in $\mathrm{XGeF}_{3} \cdots \mathrm{NH}_{3}$ or $\mathrm{XSnF}_{3} \cdots \mathrm{NH}_{3}$ should be smaller than $\mathrm{XSiF}_{3} \cdots \mathrm{NH}_{3}$, making these complexes substantially more stable than $\mathrm{XSiF}_{3} \cdots \mathrm{NH}_{3}$.

Although all complexes discussed in this paper represent the most stable tetrel-bonded complexes, not all of them represent the most stable structure possible (global minimum). For example, the hydrogen bonded complexes $\mathrm{FH} \cdots \mathrm{CFH}_{3}(\mathbf{1}), \mathrm{OH}_{2} \cdots \mathrm{CF}_{3} \mathrm{H}(2), \mathrm{NH}_{3} \cdots \mathrm{CF}_{3} \mathrm{H}$ (3) are more stable than the tetrel-bonded complexes. However, a detailed analysis of the competition between tetrel bonds and other noncovalent interactions will be studied in the near future.

Supplementary Materials: The following are available online, Figure S1: Schematic representation of monomers (36-63) with atomic charges from the natural population analysis, Figure S2: Noncovalent interactions (NCIs) plot of complexes 1-35, Figure S3: Selected molecular orbitals of the T-acceptors, Figure S4: Electron difference density distributions $\Delta \rho(\mathbf{r})$ for complexes 1-35, Figure S5: Combination of donor and acceptor NBO orbitals involved in the electron delocalization of selected complexes; Table S1: Comparison between DLPNO-CCSD(T)/aug-cc-pV5Z and CCSD(T)/aug-cc-pVTZ energies, Table S2: Deviation from DLPNO-CCSD(T)/aug-cc-pV5Z interaction energies, Table S3: Atomic Cartesian coordinates in $\AA$ of complexes 1-35.

Author Contributions: Conceptualization, D.S., V.O., and E.K.; Methodology, E.K.; Formal Analysis, D.S. and V.O.; Investigation, D.S. and V.O.; Data Curation, D.S. and V.O.; Writing-Original Draft Preparation, D.S. and V.O.; Writing-Review \& Editing, E.K.; Visualization, D.S. and V.O.; Supervision, E.K. 
Funding: This research was funded by National Science Foundation grant number CHE 1464906.

Acknowledgments: We thank Alan Humason for proof-reading and also SMU's HPC for providing excellent computational resources.

Conflicts of Interest: The authors declare no conflict of interest.

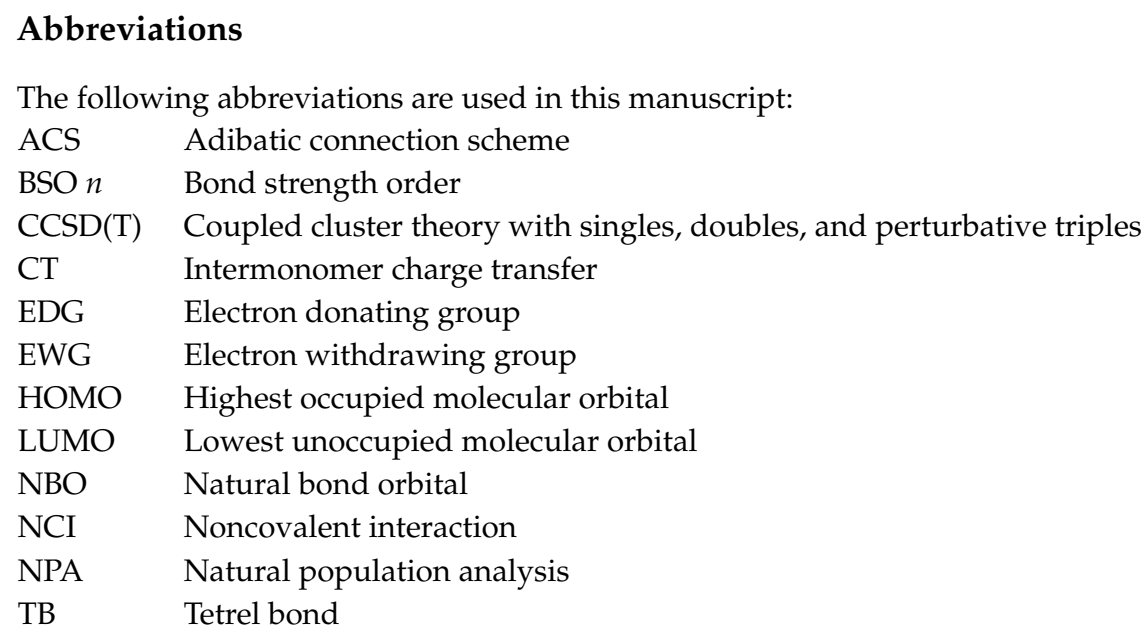

\section{References}

1. Schneider, H.J. Binding Mechanisms in Supramolecular Complexes. Angew. Chem. Int. Ed. 2009, 48, 3924-3977. [CrossRef] [PubMed]

2. Bene, J.E.D.; Alkorta, I.; Elguero, J. Exploring the $\left(\mathrm{H}_{2} \mathrm{C}=\mathrm{PH}_{2}\right)^{+}: \mathrm{N}-$ Base Potential Surfaces: Complexes Stabilized by Pnicogen, Hydrogen, and Tetrel Bonds. J. Phys. Chem. A 2015, 119, 11701-11710. [CrossRef] [PubMed]

3. Politzer, P.; Murray, J.S. Analysis of Halogen and Other $\sigma$-Hole Bonds in Crystals. Crystals 2018, 8, 42. [CrossRef]

4. Dubecký, M.; Mitas, L.; Jurečka, P. Noncovalent Interactions by Quantum Monte Carlo. Chem. Rev. 2016, 116, 5188-5215. [CrossRef] [PubMed]

5. Scheiner, S. Hydrogen Bonding: A Theoretical Perspective; Oxford University Press: New York, NY, USA, 1997.

6. Johnson, E.R.; Keinan, S.; Mori-Sánchez, P.; Contreras-García, J.; Cohen, A.J.; Yang, W. Revealing Noncovalent Interactions. J. Am. Chem. Soc. 2010, 132, 6498-6506. [CrossRef] [PubMed]

7. Riley, K.E.; Hobza, P. Noncovalent interactions in biochemistry. WIREs: Comput. Mol. Sci. 2011, 1, 3-17. [CrossRef]

8. Alkorta, I.; Legon, A. Nucleophilicities of Lewis Bases B and Electrophilicities of Lewis Acids A Determined

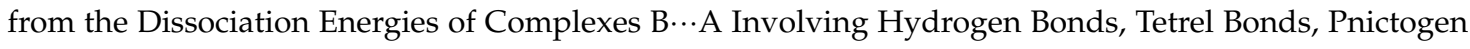
Bonds, Chalcogen Bonds and Halogen Bonds. Molecules 2017, 22, 1786. [CrossRef] [PubMed]

9. Gholipour, A. Mutual interplay between pnicogen- $\pi$ and tetrel bond in $\mathrm{PF}_{3} \perp \mathrm{X}-\mathrm{Pyr} \cdots \mathrm{SiH}_{3} \mathrm{CN}$ complexes: NMR, SAPT, AIM, NBO, and MEP analysis. Struct. Chem. 2018. [CrossRef]

10. Christensen, A.S.; Kubař, T.; Cui, Q.; Elstner, M. Semiempirical Quantum Mechanical Methods for Noncovalent Interactions for Chemical and Biochemical Applications. Chem. Rev. 2016, 116, 5301-5337. [CrossRef] [PubMed]

11. Sessions, R.B.; Gibbs, N.; Dempsey, C.E. Hydrogen Bonding in Helical Polypeptides from Molecular Dynamics Simulations and Amide Hydrogen Exchange Analysis: Alamethicin and Melittin in Methanol. Biophys. J. 1998, 74, 138-152. [CrossRef]

12. Bene, J.E.D.; Alkorta, I.; Elguero, J. Anionic complexes of $\mathrm{F}^{-}$and $\mathrm{Cl}^{-}$with substituted methanes: Hydrogen, halogen, and tetrel bonds. Chem. Phys. Lett. 2016, 655-656, 115-119. [CrossRef]

13. Priimagi, A.; Cavallo, G.; Metrangolo, P.; Resnati, G. The Halogen Bond in the Design of Functional Supramolecular Materials: Recent Advances. Acc. Chem. Res. 2013, 46, 2686-2695. [CrossRef] [PubMed] 
14. Shi, F.Q.; Li, X.; Xia, Y.; Zhang, L.; Yu, Z.X. DFT Study of the Mechanisms of In Water Au(I)-Catalyzed Tandem [3,3]-Rearrangement/Nazarov Reaction/[1,2]-Hydrogen Shift of Enynyl Acetates: A Proton-Transport Catalysis Strategy in the Water-Catalyzed [1,2]-Hydrogen Shift. J. Am. Chem. Soc. 2007, 129, 15503-15512. [CrossRef] [PubMed]

15. Shen, Q.J.; Jin, W.J. Strong halogen bonding of 1,2-diiodoperfluoroethane and 1,6-diiodoperfluorohexane with halide anions revealed by UV-Vis, FT-IR, NMR spectroscopes and crystallography. Phys. Chem. Chem. Phys. 2011, 13, 13721-13729. [CrossRef] [PubMed]

16. Arunan, E.; Desiraju, G.R.; Klein, R.A.; Sadlej, J.; Scheiner, S.; Alkorta, I.; Clary, D.C.; Crabtree, R.H.; Dannenberg, J.J.; Hobza, P.; et al. Definition of the hydrogen bond (IUPAC Recommendations 2011). Pure Appl. Chem. 2011, 83, 1637-1641. [CrossRef]

17. Arunan, E.; Desiraju, G.R.; Klein, R.A.; Sadlej, J.; Scheiner, S.; Alkorta, I.; Clary, D.C.; Crabtree, R.H.; Dannenberg, J.J.; Hobza, P.; et al. Defining the hydrogen bond: An account (IUPAC Technical Report). Pure Appl. Chem. 2011, 83, 1619-1636. [CrossRef]

18. Freindorf, M.; Kraka, E.; Cremer, D. A comprehensive analysis of hydrogen bond interactions based on local vibrational modes. Int. J. Quant. Chem. 2012, 112, 3174-3187. [CrossRef]

19. Kalescky, R.; Zou, W.; Kraka, E.; Cremer, D. Local vibrational modes of the water dimer-Comparison of theory and experiment. Chem. Phys. Lett. 2012, 554, 243-247. [CrossRef]

20. Kalescky, R.; Kraka, E.; Cremer, D. Local vibrational modes of the formic acid dimer-The strength of the double hydrogen bond. Mol. Phys. 2013, 111, 1497-1510. [CrossRef]

21. Kraka, E.; Freindorf, M.; Cremer, D. Chiral Discrimination by Vibrational Spectroscopy Utilizing Local Modes. Chirality 2013, 25, 185-196. [CrossRef] [PubMed]

22. Tao, Y.; Zou, W.; Jia, J.; Li, W.; Cremer, D. Different Ways of Hydrogen Bonding in Water-Why Does Warm Water Freeze Faster than Cold Water? J. Theory Comp. Chem. 2016, 13, 55-76. [CrossRef] [PubMed]

23. Bauzá, A.; Frontera, A. Aerogen Bonding Interaction: A New Supramolecular Force? Angew. Chem. Int. Ed. 2015, 54, 7340-7343. [CrossRef] [PubMed]

24. Bauzá, A.; Frontera, A. Theoretical Study on the Dual Behavior of $\mathrm{XeO}_{3}$ and $\mathrm{XeF}_{4}$ toward Aromatic Rings: Lone Pair- $\pi$ versus Aerogen- $\pi$ Interactions. ChemPhysChem 2015, 16, 3625-3630. [CrossRef] [PubMed]

25. Bauzá, A.; Frontera, A. $\pi$-Hole aerogen bonding interactions. Phys. Chem. Chem. Phys. 2015, 17, $24748-24753$. [CrossRef] [PubMed]

26. Frontera, A.; Bauzá, A. Concurrent aerogen bonding and lone pair/anion- $\pi$ interactions in the stability of organoxenon derivatives: A combined CSD and ab initio study. Phys. Chem. Chem. Phys. 2017, 19, 30063-30068. [CrossRef] [PubMed]

27. Desiraju, G.R.; Ho, P.S.; Kloo, L.; Legon, A.C.; Marquardt, R.; Metrangolo, P.; Politzer, P.; Resnati, G.; Rissanen, K. Definition of the halogen bond (IUPAC Recommendations 2013). Pure Appl. Chem. 2013, 85, 1711-1713. [CrossRef]

28. Politzer, P.; Murray, J.S. Halogen Bonding: An Interim Discussion. ChemPhysChem 2013, 14, $278-294$. [CrossRef] [PubMed]

29. Cavallo, G.; Metrangolo, P.; Milani, R.; Pilati, T.; Priimagi, A.; Resnati, G.; Terraneo, G. The Halogen Bond. Chem. Rev. 2016, 116, 2478-2601. [CrossRef] [PubMed]

30. Oliveira, V.; Kraka, E.; Cremer, D. The intrinsic strength of the halogen bond: Electrostatic and covalent contributions described by coupled cluster theory. Phys. Chem. Chem. Phys. 2016, 18, 33031-33046. [CrossRef] [PubMed]

31. Gilday, L.C.; Robinson, S.W.; Barendt, T.A.; Langton, M.J.; Mullaney, B.R.; Beer, P.D. Halogen Bonding in Supramolecular Chemistry. Chem. Rev. 2015, 115, 7118-7195. [CrossRef] [PubMed]

32. Wolters, L.P.; Schyman, P.; Pavan, M.J.; Jorgensen, W.L.; Bickelhaupt, F.M.; Kozuch, S. The many faces of halogen bonding: A review of theoretical models and methods. WIREs Comput. Mol. Sci. 2014, 4, 523-540. [CrossRef]

33. Alikhani, E.; Fuster, F.; Madebene, B.; Grabowski, S.J. Topological reaction sites-Very strong chalcogen bonds. Phys. Chem. Chem. Phys. 2014, 16, 2430-2442. [CrossRef] [PubMed]

34. Oliveira, V.; Cremer, D.; Kraka, E. The Many Facets of Chalcogen Bonding: Described by Vibrational Spectroscopy. J. Phys. Chem. A 2017, 121, 6845-6862. [CrossRef] [PubMed] 
35. Gleiter, R.; Haberhauer, G.; Werz, D.B.; Rominger, F.; Bleiholder, C. From Noncovalent Chalcogen-Chalcogen Interactions to Supramolecular Aggregates: Experiments and Calculations. Chem. Rev. 2018, 118, 2010-2041. [CrossRef] [PubMed]

36. Mahmudov, K.T.; Kopylovich, M.N.; da Silva, M.F.C.G.; Pombeiro, A.J.L. Chalcogen bonding in synthesis, catalysis and design of materials. Dalton Trans. 2017, 46, 10121-10138. [CrossRef] [PubMed]

37. Alkorta, I.; Elguero, J.; Bene, J.E.D. Complexes of $\mathrm{O}=\mathrm{C}=\mathrm{S}$ with Nitrogen Bases: Chalcogen Bonds, Tetrel Bonds, and Other Secondary Interactions. ChemPhysChem 2018, 19, 1886-1894. [CrossRef] [PubMed]

38. Scheiner, S. The Pnicogen Bond: Its Relation to Hydrogen, Halogen, and Other Noncovalent Bonds. Acc. Chem. Res. 2012, 46, 280-288. [CrossRef] [PubMed]

39. Sarkar, S.; Pavan, M.S.; Row, T.N.G. Experimental validation of 'pnicogen bonding' in nitrogen by charge density analysis. Phys. Chem. Chem. Phys. 2015, 17, 2330-2334. [CrossRef] [PubMed]

40. Setiawan, D.; Kraka, E.; Cremer, D. Strength of the Pnicogen Bond in Complexes Involving Group 5A Elements N, P, and As. J. Phys. Chem. A 2014, 119, 1642-1656. [CrossRef] [PubMed]

41. Setiawan, D.; Kraka, E.; Cremer, D. Description of pnicogen bonding with the help of vibrational spectroscopy-The missing link between theory and experiment. Chem. Phys. Lett. 2014, 614, 136-142. [CrossRef]

42. Setiawan, D.; Cremer, D. Super-pnicogen bonding in the radical anion of the fluorophosphine dimer. Chem. Phys. Lett. 2016, 662, 182-187. [CrossRef]

43. Thomas, S.P.; Pavan, M.S.; Row, T.N.G. Experimental evidence for 'carbon bonding' in the solid state from charge density analysis. Chem. Commun. 2014, 50, 49-51. [CrossRef] [PubMed]

44. Bauzá, A.; Mooibroek, T.J.; Frontera, A. Tetrel-Bonding Interaction: Rediscovered Supramolecular Force? Angew. Chem. Int. Ed. 2013, 52, 12317-12321. [CrossRef] [PubMed]

45. Bauzá, A.; Mooibroek, T.J.; Frontera, A. Tetrel Bonding Interactions. Chem. Rec. 2016, 16, 473-487. [CrossRef] [PubMed]

46. Bene, J.E.D.; Alkorta, I.; Elguero, J. Carbenes as Electron-Pair Donors $\mathrm{To}^{\mathrm{CO}}$ for C $\cdots \mathrm{C}$ Tetrel Bonds and C-C Covalent Bonds. J. Phys. Chem. A 2017, 121, 4039-4047. [CrossRef] [PubMed]

47. Alkorta, I.; Elguero, J.; Bene, J.E.D. Azines as Electron-Pair Donors to $\mathrm{CO}_{2}$ for $\mathrm{N} \cdots \mathrm{C}$ Tetrel Bonds. J. Phys. Chem. A 2017, 121, 8017-8025. [CrossRef] [PubMed]

48. Bene, J.E.D.; Alkorta, I.; Elguero, J. Carbon-Carbon Bonding between Nitrogen Heterocyclic Carbenes and $\mathrm{CO}_{2}$. J. Phys. Chem. A 2017, 121, 8136-8146. [CrossRef] [PubMed]

49. Bene, J.D.; Elguero, J.; Alkorta, I. Complexes of $\mathrm{CO}_{2}$ with the Azoles: Tetrel Bonds, Hydrogen Bonds and Other Secondary Interactions. Molecules 2018, 23, 906. [CrossRef] [PubMed]

50. Grabowski, S.J. Triel Bonds, $\pi$-Hole- $\pi$-Electrons Interactions in Complexes of Boron and Aluminium Trihalides and Trihydrides with Acetylene and Ethylene. Molecules 2015, 20, 11297-11316. [CrossRef] [PubMed]

51. Bauzá, A.; Frontera, A. On the Versatility of $\mathrm{BH}_{2} \mathrm{X}(\mathrm{X}=\mathrm{F}, \mathrm{Cl}, \mathrm{Br}$, and $\mathrm{I})$ Compounds as Halogen-, Hydrogen-, and Triel-Bond Donors: An Ab Initio Study. ChemPhysChem 2016, 17, 3181-3186. [CrossRef] [PubMed]

52. Esrafili, M.D.; Asadollahi, S.; Mousavian, P. Anionic tetrel bonds: An ab initio study. Chem. Phys. Lett. 2018, 691, 394-400. [CrossRef]

53. Li, Q.Z.; Zhuo, H.Y.; Li, H.B.; Liu, Z.B.; Li, W.Z.; Cheng, J.B. Tetrel-Hydride Interaction between $\mathrm{XH}_{3} \mathrm{~F}(\mathrm{X}=$ $\mathrm{C}, \mathrm{Si}, \mathrm{Ge}, \mathrm{Sn})$ and HM (M = Li, Na, BeH, MgH). J. Phys. Chem. A 2014, 119, 2217-2224. [CrossRef] [PubMed]

54. Lu, Y.; Wang, Y.; Zhu, W. Nonbonding interactions of organic halogens in biological systems: Implications for drug discovery and biomolecular design. Phys. Chem. Chem. Phys. 2010, 12, 4543-4551. [CrossRef] [PubMed]

55. Mani, D.; Arunan, E. The $\mathrm{X}-\mathrm{C} \cdots \pi(\mathrm{X}=\mathrm{F}, \mathrm{Cl}, \mathrm{Br}, \mathrm{CN})$ Carbon Bond. J. Phys. Chem. A 2014, 118, 10081-10089. [CrossRef] [PubMed]

56. Xu, H.; Cheng, J.; Yang, X.; Liu, Z.; Li, W.; Li, Q. Comparison of $\sigma$-Hole and $\pi$-Hole Tetrel Bonds Formed by Pyrazine and 1,4-Dicyanobenzene: The Interplay between Anion- $\pi$ and Tetrel Bonds. ChemPhysChem 2017, 18, 2442-2450. [CrossRef] [PubMed]

57. Grabowski, S.J. Tetrel bond- $\sigma$-hole bond as a preliminary stage of the $\mathrm{SN}_{2}$ reaction. Phys. Chem. Chem. Phys. 2014, 16, 1824-1834. [CrossRef] [PubMed]

58. Murray, J.S.; Lane, P.; Politzer, P. Expansion of the $\sigma$-hole concept. J. Mol. Model. 2009, 15, 723-729. [CrossRef] [PubMed] 
59. Scilabra, P.; Kumar, V.; Ursini, M.; Resnati, G. Close contacts involving germanium and tin in crystal structures: Experimental evidence of tetrel bonds. J. Mol. Model. 2018, 24, 37. [CrossRef] [PubMed]

60. Donald, K.J.; Tawfik, M. The Weak Helps the Strong: Sigma-Holes and the Stability of $\mathrm{MF}_{4} \cdot$ Base Complexes. J. Phys. Chem. A 2013, 117, 14176-14183. [CrossRef] [PubMed]

61. Bundhun, A.; Ramasami, P.; Murray, J.S.; Politzer, P. Trends in $\sigma$-hole strengths and interactions of $\mathrm{F}_{3} \mathrm{MX}$ molecules ( $\mathrm{M}=\mathrm{C}$, Si, Ge and X = F, Cl, Br, I). J. Mol. Model. 2013, 19, 2739-2746. [CrossRef] [PubMed]

62. Scheiner, S. Comparison of $\mathrm{CH} \cdots \mathrm{O}, \mathrm{SH} \cdots \mathrm{O}$, Chalcogen, and Tetrel Bonds Formed by Neutral and Cationic Sulfur-Containing Compounds. J. Phys. Chem. A 2015, 119, 9189-9199. [CrossRef] [PubMed]

63. Azofra, L.M.; Scheiner, S. Tetrel, chalcogen, and $\mathrm{CH}$... O hydrogen bonds in complexes pairing carbonylcontaining molecules with 1, 2, and 3 molecules of $\mathrm{CO}_{2}$. J. Chem. Phys. 2015, 142, 034307. [CrossRef] [PubMed]

64. Wei, Y.; Li, Q.; Scheiner, S. The $\pi$-Tetrel Bond and its Influence on Hydrogen Bonding and Proton Transfer. ChemPhysChem 2018, 19, 736-743. [CrossRef] [PubMed]

65. McDowell, S.A.C.; Joseph, J.A. The effect of atomic ions on model $\sigma$-hole bonded complexes of $\mathrm{AH}_{3} \mathrm{Y}$ (A = C, Si, Ge; Y = F, Cl, Br). Phys. Chem. Chem. Phys. 2014, 16, 10854. [CrossRef] [PubMed]

66. Politzer, P.; Murray, J.S.; Clark, T. Halogen bonding and other $\sigma$-hole interactions: A perspective. Phys. Chem. Chem. Phys. 2013, 15, 11178-11189. [CrossRef] [PubMed]

67. Politzer, P.; Murray, J.S. $\sigma$-Hole Interactions: Perspectives and Misconceptions. Crystals 2017, 7, 212. [CrossRef]

68. Politzer, P.; Murray, J.S.; Clark, T.; Resnati, G. The $\sigma$-hole revisited. Phys. Chem. Chem. Phys. 2017, 19, 32166-32178. [CrossRef] [PubMed]

69. Clark, T.; Hennemann, M.; Murray, J.S.; Politzer, P. Halogen bonding: The $\sigma$-hole. J. Mol. Model. 2007, 13, 291-296. [CrossRef] [PubMed]

70. Jönsson, B.; Karlström, G.; Wennerström, H. Ab initio molecular orbital calculations on the water-carbon dioxide system: Molecular complexes. Chem. Phys. Lett. 1975, 30, 58-59. [CrossRef]

71. Peterson, K.I.; Klemperer, W. Structure and internal rotation of $\mathrm{H}_{2} \mathrm{O}-\mathrm{CO}_{2}, \mathrm{HDO}-\mathrm{CO}_{2}$, and $\mathrm{D}_{2} \mathrm{O}-\mathrm{CO}_{2}$ van der Waals complexes. J. Chem. Phys. 1984, 80, 2439-2445. [CrossRef]

72. Mitzel, N.W.; Blake, A.J.; Rankin, D.W.H. $\beta$-Donor Bonds in SiON Units: An Inherent Structure- Determining Property Leading to (4+4)-Coordination in Tetrakis-(N,N-dimethylhydroxylamido)silane. J. Am. Chem. Soc. 1997, 119, 4143-4148. [CrossRef]

73. Mitzel, N.W.; Losehand, U. $\beta$-Donorbindungen in Molekülen mit SiON-Einheiten. Angew. Chem. 1997, 109, 2897-2899. [CrossRef]

74. Southern, S.A.; Bryce, D.L. NMR Investigations of Noncovalent Carbon Tetrel Bonds. Computational Assessment and Initial Experimental Observation. J. Phys. Chem. A 2015, 119, 11891-11899. [CrossRef] [PubMed]

75. Brammer, L. Halogen bonding, chalcogen bonding, pnictogen bonding, tetrel bonding: Origins, current status and discussion. Faraday Discuss. 2017, 203, 485-507. [CrossRef] [PubMed]

76. Li, R.; Li, Q.; Cheng, J.; Liu, Z.; Li, W. The Prominent Enhancing Effect of the Cation- $\pi$ Interaction on the Halogen-Hydride Halogen Bond in $\mathrm{M}^{1} \cdots \mathrm{C}_{6} \mathrm{H}_{5} \mathrm{X} \cdots \mathrm{HM}^{2}$. ChemPhysChem 2011, 12, 2289-2295. [CrossRef] [PubMed]

77. Li, Q.Z.; Sun, L.; Liu, X.F.; Li, W.Z.; Cheng, J.B.; Zeng, Y.L. Enhancement of Iodine-Hydride Interaction by Substitution and Cooperative Effects in NCX-NCI-HMY Complexes. ChemPhysChem 2012, 13, 3997-4002. [CrossRef] [PubMed]

78. George, J.; Dronskowski, R. Tetrel Bonds in Infinite Molecular Chains by Electronic Structure Theory and Their Role for Crystal Stabilization. J. Phys. Chem. A 2017, 121, 1381-1387. [CrossRef] [PubMed]

79. Tang, Q.; Li, Q. Interplay between tetrel bonding and hydrogen bonding interactions in complexes involving $\mathrm{F}_{2} \mathrm{XO}(\mathrm{X}=\mathrm{C}$ and $\mathrm{Si})$ and HCN. Comput. Theor. Chem. 2014, 1050, 51-57. [CrossRef]

80. Liu, M.; Li, Q.; Li, W.; Cheng, J.; McDowell, S.A.C. Comparison of hydrogen, halogen, and tetrel bonds in the complexes of HArF with $\mathrm{YH}_{3} \mathrm{X}(\mathrm{X}=$ halogen, $\mathrm{Y}=\mathrm{C}$ and $\mathrm{Si})$. RSC Adv. 2016, 6, 19136-19143. [CrossRef]

81. Guo, X.; Liu, Y.W.; Li, Q.Z.; Li, W.Z.; Cheng, J.B. Competition and cooperativity between tetrel bond and chalcogen bond in complexes involving $\mathrm{F}_{2} \mathrm{CX}(\mathrm{X}=\mathrm{Se}$ and Te). Chem. Phys. Lett. 2015, 620, 7-12. [CrossRef]

82. Marín-Luna, M.; Alkorta, I.; Elguero, J. Cooperativity in Tetrel Bonds. J. Phys. Chem. A 2016, 120, 648-656. [CrossRef] [PubMed] 
83. Solimannejad, M.; Orojloo, M.; Amani, S. Effect of cooperativity in lithium bonding on the strength of halogen bonding and tetrel bonding: $(\mathrm{LiCN})_{n} \cdots \mathrm{ClYF}_{3}$ and $(\mathrm{LiCN})_{n} \cdots \mathrm{YF}_{3} \mathrm{Cl}(\mathrm{Y}=\mathrm{C}$, $\mathrm{Si}$ and $\mathrm{n}=1-5)$ complexes as a working model. J. Mol. Model. 2015, 21. [CrossRef] [PubMed]

84. Esrafili, M.D.; Mohammadirad, N.; Solimannejad, M. Tetrel bond cooperativity in open-chain $\left(\mathrm{CH}_{3} \mathrm{CN}\right)_{n}$ and $\left(\mathrm{CH}_{3} \mathrm{NC}\right)_{n}$ clusters ( $\left.\mathrm{n}=2-7\right)$ : An ab initio study. Chem. Phys. Lett. 2015, 628, 16-20. [CrossRef]

85. Liu, M.; Li, Q.; Li, W.; Cheng, J. Tetrel bonds between PySiX 3 and some nitrogenated bases: Hybridization, substitution, and cooperativity. J. Mol. Graphics Modell. 2016, 65, 35-42. [CrossRef] [PubMed]

86. Wei, Y.; Li, Q.; Yang, X.; McDowell, S.A.C. Intramolecular Si ‥O Tetrel Bonding: Tuning of Substituents and Cooperativity. ChemistrySelect 2017, 2, 11104-11112. [CrossRef]

87. Wei, Y.; Cheng, J.; Li, W.; Li, Q. Regulation of coin metal substituents and cooperativity on the strength and nature of tetrel bonds. RSC Adv. 2017, 7, 46321-46328. [CrossRef]

88. Mani, D.; Arunan, E. The X-C ‥Y Carbon Bond. In Noncovalent Forces; Springer International Publishing: Cham, Switzerland, 2015; pp. 323-356.

89. Mahadevi, A.S.; Sastry, G.N. Cooperativity in Noncovalent Interactions. Chem. Rev. 2016, 116, $2775-2825$. [CrossRef] [PubMed]

90. Politzer, P.; Murray, J.S. The fundamental nature and role of the electrostatic potential in atoms and molecules. Theor. Chem. Acc. 2002, 108, 134-142. [CrossRef]

91. Murray, J.S.; Politzer, P. The electrostatic potential: An overview. WIREs Comput. Mol. Sci. 2011, 1, 153-163. [CrossRef]

92. Mani, D.; Arunan, E. The $\mathrm{X}-\mathrm{C} \cdots \mathrm{Y}(\mathrm{X}=\mathrm{O} / \mathrm{F}, \mathrm{Y}=\mathrm{O} / \mathrm{S} / \mathrm{F} / \mathrm{Cl} / \mathrm{Br} / \mathrm{N} / \mathrm{P})$ 'carbon bond' and hydrophobic interactions. Phys. Chem. Chem. Phys. 2013, 15, 14377-14383. [CrossRef] [PubMed]

93. Zierkiewicz, W.; Michalczyk, M.; Scheiner, S. Comparison between Tetrel Bonded Complexes Stabilized by $\sigma$ and $\pi$ Hole Interactions. Molecules 2018, 23, 1416. [CrossRef] [PubMed]

94. Zierkiewicz, W.; Michalczyk, M.; Scheiner, S. Implications of monomer deformation for tetrel and pnicogen bonds. Phys. Chem. Chem. Phys. 2018, 20, 8832-8841. [CrossRef] [PubMed]

95. Cremer, D.; Kraka, E. From Molecular Vibrations to Bonding, Chemical Reactions, and Reaction Mechanism. Curr. Org. Chem. 2010, 14, 1524-1560. [CrossRef]

96. Kraka, E.; Setiawan, D.; Cremer, D. Re-evaluation of the Bond Length-Bond Strength Rule: The Stronger Bond Is not Always the Shorter Bond. J. Comp. Chem. 2016, 37, 130-142. [CrossRef] [PubMed]

97. Setiawan, D.; Kraka, E.; Cremer, D. Hidden Bond Anomalies: The Peculiar Case of the Fluorinated Amine Chalcogenides. J. Phys. Chem. A 2015, 119, 9541-9556. [CrossRef] [PubMed]

98. Setiawan, D.; Sethio, D.; Cremer, D.; Kraka, E. From strong to weak NF bonds: On the design of a new class of fluorinating agents. Phys. Chem. Chem. Phys. 2018, 20, 23913-23927. [CrossRef] [PubMed]

99. Lin, C.Y.; Gilbert, A.T.B.; Gill, P.M.W. Calculating molecular vibrational spectra beyond the harmonic approximation. Theor. Chem. Acc. 2007, 120, 23-35. [CrossRef]

100. Roy, T.K.; Gerber, R.B. Vibrational self-consistent field calculations for spectroscopy of biological molecules: New algorithmic developments and applications. Phys. Chem. Chem. Phys. 2013, 15, 9468-9492. [CrossRef] [PubMed]

101. Panek, P.T.; Jacob, C.R. Anharmonic Theoretical Vibrational Spectroscopy of Polypeptides. J. Phys. Chem. Lett. 2016, 7, 3084-3090. [CrossRef] [PubMed]

102. Konkoli, Z.; Cremer, D. A New Way of Analyzing Vibrational Spectra I. Derivation of Adiabatic Internal Modes. Int. J. Quant. Chem. 1998, 67, 1-9. [CrossRef]

103. Konkoli, Z.; Larsson, J.A.; Cremer, D. A new way of analyzing vibrational spectra. IV. Application and testing of adiabatic modes within the concept of the characterization of normal modes. Int. J. Quant. Chem. 1998, 67, 41-55. [CrossRef]

104. Zou, W.; Kalescky, R.; Kraka, E.; Cremer, D. Relating Normal Vibrational Modes to Local Vibrational Modes with the Help of an Adiabatic Connection Scheme. J. Chem. Phys. 2012, 137, 084114. [CrossRef] [PubMed]

105. Kalescky, R.; Kraka, E.; Cremer, D. Description of Aromaticity with the Help of Vibrational Spectroscopy: Anthracene and Phenanthrene. J. Phys. Chem. A 2014, 118, 223-237. [CrossRef] [PubMed]

106. Freindorf, M.; Tao, Y.; Sethio, D.; Cremer, D.; Kraka, E. New Mechanistic Insights into the Claisen Rearrangement of Chorismate-A Unified Reaction Valley Approach Study. Mol. Phys. 2018, in press. [CrossRef] 
107. Cremer, D.; Larsson, J.A.; Kraka, E. New developments in the analysis of vibrational spectra On the use of adiabatic internal vibrational modes. In Theoretical and Computational Chemistry; Parkanyi, C., Ed.; Elsevier: Amsterdam, The Netherlands, 1998; pp. 259-327.

108. Zou, W.; Kalescky, R.; Kraka, E.; Cremer, D. Relating normal vibrational modes to local vibrational modes: Benzene and naphthalene. J. Mol. Model. 2012, 19, 2865-2877. [CrossRef] [PubMed]

109. Humason, A.; Zou, W.; Cremer, D. 11,11-Dimethyl-1,6-methano[10]annulene-An Annulene with an Ultralong CC Bond or a Fluxional Molecule? J. Phys. Chem. A 2015, 119, 1666-1682. [CrossRef] [PubMed]

110. Kalescky, R.; Kraka, E.; Cremer, D. Identification of the Strongest Bonds in Chemistry. J. Phys. Chem. A 2013, 117, 8981-8995. [CrossRef] [PubMed]

111. Kalescky, R.; Kraka, E.; Cremer, D. New Approach to Tolman's Electronic Parameter Based on Local Vibrational Modes. Inorg. Chem. 2014, 53, 478-495. [CrossRef] [PubMed]

112. Kraka, E.; Cremer, D. Characterization of CF Bonds with Multiple-Bond Character: Bond Lengths, Stretching Force Constants, and Bond Dissociation Energies. ChemPhysChem 2009, 10, 686-698. [CrossRef] [PubMed]

113. Kalescky, R.; Kraka, E.; Cremer, D. Are carbon-halogen double and triple bonds possible? Int. J. Quantum Chem. 2014, 114, 1060-1072. [CrossRef]

114. Kalescky, R.; Zou, W.; Kraka, E.; Cremer, D. Quantitative Assessment of the Multiplicity of Carbon-Halogen Bonds: Carbenium and Halonium Ions with F, Cl, Br, and I. J. Phys. Chem. A 2014, 118, 1948-1963. [CrossRef] [PubMed]

115. Oomens, J.; Kraka, E.; Nguyen, M.K.; Morton, T.H. Structure, Vibrational Spectra, and Unimolecular Dissociation of Gaseous 1-Fluoro-1-phenethyl Cations. J. Phys. Chem. A 2008, 112, 10774-10783. [CrossRef] [PubMed]

116. Oliveira, V.; Kraka, E.; Cremer, D. Quantitative Assessment of Halogen Bonding Utilizing Vibrational Spectroscopy. Inorg. Chem. 2016, 56, 488-502. [CrossRef] [PubMed]

117. Oliveira, V.; Kraka, E. Systematic Coupled Cluster Study of Noncovalent Interactions Involving Halogens, Chalcogens, and Pnicogens. J. Phys. Chem. A 2017, 121, 9544-9556. [CrossRef] [PubMed]

118. Oliveira, V.; Cremer, D. Transition from metal-ligand bonding to halogen bonding involving a metal as halogen acceptor a study of $\mathrm{Cu}, \mathrm{Ag}, \mathrm{Au}, \mathrm{Pt}$, and $\mathrm{Hg}$ complexes. Chem. Phys. Lett. 2017, 681, 56-63. [CrossRef]

119. Zhang, X.; Dai, H.; Yan, H.; Zou, W.; Cremer, D. B-H $\cdots \pi$ Interaction: A New Type of Nonclassical Hydrogen Bonding. J. Am. Chem. Soc. 2016, 138, 4334-4337. [CrossRef] [PubMed]

120. Zou, W.; Zhang, X.; Dai, H.; Yan, H.; Cremer, D.; Kraka, E. Description of an unusual hydrogen bond between carborane and a phenyl group. J. Organ. Chem. 2018, 865, 114-127. [CrossRef]

121. Purvis, G.D.; Bartlett, R.J. A full coupled-cluster singles and doubles model: The inclusion of disconnected triples. J. Chem. Phys. 1982, 76, 1910-1918. [CrossRef]

122. Pople, J.A.; Head-Gordon, M.; Raghavachari, K. Quadratic configuration interaction. A general technique for determining electron correlation energies. J. Chem. Phys. 1987, 87, 5968-5975. [CrossRef]

123. Dunning, T.H. Gaussian basis sets for use in correlated molecular calculations. I. The atoms boron through neon and hydrogen. J. Chem. Phys. 1989, 90, 1007-1023. [CrossRef]

124. Woon, D.E.; Dunning, T.H. Gaussian basis sets for use in correlated molecular calculations. III. The atoms aluminum through argon. J. Chem. Phys. 1993, 98, 1358-1371. [CrossRef]

125. Woon, D.E.; Dunning, T.H. Gaussian basis sets for use in correlated molecular calculations. IV. Calculation of static electrical response properties. J. Chem. Phys. 1994, 100, 2975-2988. [CrossRef]

126. Wilson, E.B.; Decius, J.C.; Cross, P.C. Molecular Vibrations. The Theory of Infrared and Raman Vibrational Spectra; McGraw-Hill: New York, NY, USA, 1955.

127. Kraka, E.; Larsson, J.A.; Cremer, D. Generalization of the Badger Rule Based on the Use of Adiabatic Vibrational Modes. In Computational Spectroscopy; Grunenberg, J., Ed.; Wiley: New York, NY, USA, 2010; pp. 105-149.

128. Boys, S.F.; Bernardi, F. The calculation of small molecular interactions by the differences of separate total energies. Some procedures with reduced errors. Mol. Phys. 1970, 19, 553-566. [CrossRef]

129. Mentel, Ł.M.; Baerends, E.J. Can the Counterpoise Correction for Basis Set Superposition Effect Be Justified? J. Chem. Theory Comput. 2013, 10, 252-267. [CrossRef] [PubMed]

130. Riplinger, C.; Neese, F. An efficient and near linear scaling pair natural orbital based local coupled cluster method. J. Chem. Phys. 2013, 138, 034106. [CrossRef] [PubMed] 
131. Riplinger, C.; Sandhoefer, B.; Hansen, A.; Neese, F. Natural triple excitations in local coupled cluster calculations with pair natural orbitals. J. Chem. Phys. 2013, 139, 134101. [CrossRef] [PubMed]

132. Stanton, J.F.; Gauss, J.; Cheng, L.; Harding, M.E.; Matthews, D.A.; Szalay, P.G. CFOUR, Coupled-Cluster techniques for Computational Chemistry, a Quantum-Chemical Program Package. Available online: http: / / www.cfour.de (accessed on 1 October 2018).

133. Harding, M.; Mezroth, T.; Gauss, J.; Auer, A. Parallel Calculation of CCSD and CCSD(T) Analytic First and Second Derivatives. J. Chem. Theory Comput. 2008, 4, 64-74. [CrossRef] [PubMed]

134. Neese, F. The ORCA program system. WIREs Comput. Mol. Sci. 2011, 2, 73-78. [CrossRef]

135. Weinhold, F.; Landis, C.R. Valency and Bonding: A Natural Bond Orbital Donor-Acceptor Perspective; Cambridge University Press: Cambridge, UK, 2003.

136. Reed, A.; Curtiss, L.; Weinhold, F. Intermolecular Interactions from A Natural Bond Orbital, Donor-Acceptor Viewpoint. Chem. Rev. 1988, 88, 899-926. [CrossRef]

137. Glendening, E.D.; Badenhoop, J.K.; Reed, A.E.; Carpenter, J.E.; Bohmann, J.A.; Morales, C.M.; Landis, C.R.; Weinhold, F. NBO6. In Theoretical Chemistry Institute; University of Wisconsin: Madison, WI, USA, 2013.

138. Glendening, E.D.; Landis, C.R.; Weinhold, F. NBO 6.0: Natural bond orbital analysis program. J. Comput. Chem. 2013, 34, 1429-1437. [CrossRef] [PubMed]

139. Keith, T. TK Gristmill Software. Overland Park, KS, USA. Available online: http//aim.tkgristmill.com (accessed on 1 October 2018).

140. Lu, T.; Chen, F. Multiwfn: A multifunctional wavefunction analyzer. J. Comput. Chem. 2011, 33, 580-592. [CrossRef] [PubMed]

141. Contreras-García, J.; Johnson, E.R.; Keinan, S.; Chaudret, R.; Piquemal, J.P.; Beratan, D.N.; Yang, W. NCIPLOT: A Program for Plotting Noncovalent Interaction Regions. J. Chem. Theory Comput. 2011, 7, 625-632. [CrossRef] [PubMed]

142. Zou, W.; Nori-Shargh, D.; Boggs, J.E. On the Covalent Character of Rare Gas Bonding Interactions: A New Kind of Weak Interaction. J. Phys. Chem. A 2012, 117, 207-212. [CrossRef] [PubMed]

143. Kraka, E.; Zou, W.; Filatov, M.; Gräfenstein, J.; Izotov, D.; Gauss, J.; He, Y.; Wu, A.; Konkoli, Z.; Polo, V.; et al. COLOGNE, 2018. Available online: http:/ / www.smu.edu/catco (accessed on 1 October 2018).

144. Li, Y.; Oliveira, V.; Tang, C.; Cremer, D.; Liu, C.; Ma, J. The Peculiar Role of the $\mathrm{Au}_{3}$ Unit in Au $\mathrm{m}_{m}$ Clusters: $\sigma$-Aromaticity of the $\mathrm{Au}_{5} \mathrm{Zn}^{+}$Ion. Inorg. Chem. 2017, 56, 5793-5803. [CrossRef] [PubMed]

145. Cremer, D.; Kraka, E. Chemical Bonds without Bonding Electron Density? Does the Difference ElectronDensity Analysis Suffice for a Description of the Chemical Bond? Angew. Chem. Int. Ed. 1984, 23, 627-628. [CrossRef]

146. Cremer, D.; Kraka, E. A Description of the Chemical Bond in Terms of Local Properties of Electron Density and Energy. Croatica Chem. Acta 1984, 57, 1259-1281.

147. Grabowski, S. Lewis Acid Properties of Tetrel Tetrafluorides-The Coincidence of the $\sigma$-Hole Concept with the QTAIM Approach. Crystals 2017, 7, 43. [CrossRef]

148. Scheiner, S. Systematic Elucidation of Factors That Influence the Strength of Tetrel Bonds. J. Phys. Chem. A 2017, 121, 5561-5568. [CrossRef] [PubMed]

149. Scheiner, S. Steric Crowding in Tetrel Bonds. J. Phys. Chem. A 2018, 122, 2550-2562. [CrossRef] [PubMed]

150. Angarov, V.; Kozuch, S. On the $\sigma, \pi$ and $\delta$ hole interactions: A molecular orbital overview. New J. Chem. 2018, 42, 1413-1422. [CrossRef]

151. Wang, H.; Wang, W.; Jin, W.J. $\sigma$-Hole Bond vs $\pi$-Hole Bond: A Comparison Based on Halogen Bond. Chem. Rev. 2016, 116, 5072-5104. [CrossRef] [PubMed]

152. Dong, W.; Wang, Y.; Cheng, J.; Yang, X.; Li, Q. Competition between $\sigma$-hole pnicogen bond and $\pi$-hole tetrel bond in complexes of $\mathrm{CF}_{2}=\mathrm{CFZH}_{2}(\mathrm{Z}=\mathrm{P}, \mathrm{As}$, and Sb). Mol. Phys. 2018, 1-9. [CrossRef]

153. Grabowski, S.J. Hydrogen bonds, and $\sigma$-hole and $\pi$-hole bonds-Mechanisms protecting doublet and octet electron structures. Phys. Chem. Chem. Phys. 2017, 19, 29742-29759. [CrossRef] [PubMed]

154. Shen, S.; Zeng, Y.; Li, X.; Meng, L.; Zhang, X. Insight into the $\pi$-holebond... $\pi$-electrons tetrel bonds between $\mathrm{F}_{2} \mathrm{ZO}(\mathrm{Z}=\mathrm{C}, \mathrm{Si}, \mathrm{Ge})$ and unsaturated hydrocarbons. Int. J. Quantum Chem. 2017, 118, e25521. [CrossRef]

155. Liu, M.; Li, Q.; Li, W.; Cheng, J. Carbene tetrel-bonded complexes. Struct. Chem. 2017, 28, 823-831. [CrossRef] 
156. Xu, H.; Cheng, J.; Yu, X.; Li, Q. Abnormal Tetrel Bonds between Formamidine and $\mathrm{TH}_{3} \mathrm{~F}$ : Substituent Effects. Chem. Sel. 2018, 3, 2842-2849.

157. Zierkiewicz, W.; Michalczyk, M. On the opposite trends of correlations between interaction energies and electrostatic potentials of chlorinated and methylated amine complexes stabilized by halogen bond. Theor. Chem. Acc. 2017, 136. [CrossRef]

(C) 2018 by the authors. Licensee MDPI, Basel, Switzerland. This article is an open access article distributed under the terms and conditions of the Creative Commons Attribution (CC BY) license (http://creativecommons.org/licenses/by/4.0/). 